\title{
Recent advances on palm oil mill effluent (POME) pretreatment and anaerobic reactor for sustainable biogas production
}

Md Maniruzzaman A Aziz

Khairul Anuar Kassim

Moetaz ElSergany, M.

Syed Anuar.

M. Ehsan Jorat.

H. Yaacob.

Amimul Ahsan.

Monzur A. Imteaz.

Arifuzzaman

This is the accepted manuscript (C) 2019, Elsevier Licensed under the Creative Commons AttributionNonCommercial-NoDerivatives 4.0 International: http://creativecommons.org/licenses/by-nc-nd/4.0/ $\left(\right.$ co) EY-No-ND $^{-1 / C r}$

The published article is available from https://doi.org/10.1016/j.rser.2019.109603 
Recent advances on palm oil mill effluent (POME) pretreatment and anaerobic reactor for sustainable biogas production

Md Maniruzzaman A Aziz ${ }^{a,}{ }^{,}$, Khairul Anuar Kassim ${ }^{a}$, Moetaz ElSergany ${ }^{b}$, Syed Anuar ${ }^{c}$, M. Ehsan Jorat $^{d}$, H. Yaacob ${ }^{\mathrm{a}}$, Amimul Ahsan ${ }^{\mathrm{e}}$, Monzur A. Imteaz ${ }^{\mathrm{f}}$, Arifuzzaman, PhD ${ }^{\mathrm{g}}$

a School of Civil Engineering, Faculty of Engineering, Universiti Teknologi Malaysia (UTM), UTM Skudai, 81310, Skudai, Johor, Malaysia

${ }^{\mathrm{b}}$ School of Health and Environmental Studies, Hamdan Bin Mohammed Smart University (HBMSU),

Dubai, United Arab Emirates

' School of Chemical and Energy Engineering, Faculty of Engineering, Universiti Teknologi Malaysia, UTM Skudai, 81310, Skudai, Johor, Malaysia

${ }^{d}$ Division of Natural and Built Environment, School of Applied Sciences, Abertay University, Dundee, UK

e Department of Civil Engineering, Uttara University, Dhaka, 1230, Bangladesh

${ }^{f}$ Department of Civil and Construction Engineering, Faculty of Science, Engineering and Technology, Swinburne University of Technology, Hawthorn, Melbourne, VIC, 3122, Australia

${ }^{g}$ King Faisal University, Al-Hofuf, Al-Ahsa, 31982, Saudi Arabia

\section{ABSTRACT}

Palm oil is one of the leading agricultural crops in the world, as it dominates $34 \%$ of the global vegetable oil market, with approximately $64.6 * 103$ million kgs of production in 2017 . However, along with its breakthrough, the generation of palm oil mill effluent (POME) as uncontrolled waste has become a serious matter and requires proper management to reduce its negative effects on the environment. Subsequently, the high organic content of POME makes it possible to convert waste into value-added products, such as biogas. A ratio of 0.5 for biological oxygen demand to chemical oxygen demand (BOD/COD) indicates a high possibility for biological treatment. Recently, the utilisation of POME as a cheap source for biogas production has gained an extraordinary amount of attention, and intensive research has been conducted on the upstream to downstream process. Finding the most suitable and efficient pretreatment technique and reactor configuration are vital parameters for the treatment and conversion of POME to biogas. This review describes existing pretreatment processes for POME and recommends recently manufactured high-rate anaerobic reactors as the most suitable and efficient pretreatment technique for maximising the extraction of biogas from POME.

Keywords: Palm oil mill effluent (POME); Pretreatment; Bioreactor; Biogas; Sustainable; Renewable energy

Nomenclature

POME Palm Oil mill Effluent

GHGs Greenhouse gases

$\mathrm{CH} 4$ Methane

CO2 Carbon dioxide

H2S Hydrogen sulphide

$\mathrm{H} 2$ Hydrogen

N2 Nitrogen (N2)

CO Carbon monoxide

O2 Oxygen

COD Chemical oxygen demand

VS Volatile solid

HRT Hydraulic retention time

MSW Municipal solid waste

CF Coagulation-flocculation 
VFA Volatile fatty acid

DAF Dissolve air flotation

CKD Cement kiln dust

AFBR Anaerobic fluidized bedreactor

ASBR Anaerobic sequencing batch reactor

CSTR Continous stirred tank reactor

EGSB Expanded granular sludge bed

UAF Upflow anaerobic filtration

UASB Upflow anaerobic sludge blanket

UASFF Up-flow anaerobic sludge fixed-film

AnaEG Advanced anaerobic expanded granular sludge bed

AnMBR Anaerobic membrane reactor

UASB HCPB-Upflow anaerobic sludge blanket-hollow centred packed bed

1. Introduction

Renewable energy can ensure that there are enough resources to satisfy future generations' global energy demands. By the year 2030, the global energy demand is expected to increase by $43 \%$, reaching 672*1.055 quadrillion kJ from $472 \times 1.055$ quadrillion kJ in 2012 [1]. Accordingly, the sole use of renewable energy resources will be insufficient to meet this global energy demand.

Renewable energy must be sustainable in economic, social, and environmental aspects. Currently, renewable energy accounts for $10 \%$ of global energy consumption and is expected to increase to $15 \%$ by 2050 [2].

Biogas is a promising renewable energy resource. This green energy resource could reduce the dependency on fossil fuels and mitigate environmental issues, such as the emission of greenhouse gases (GHGs). Biogas is a colourless and odourless gas composed of methane ( $\mathrm{CH} 4)$, carbon dioxide (CO2), a small amount of hydrogen sulphide ( $\mathrm{H} 2 \mathrm{~S})$, hydrogen $(\mathrm{H} 2)$, nitrogen (N2), and trace amounts of carbon monoxide ( $\mathrm{CO}$ ) and oxygen (O2). Biogas can be used to generate heat and electricity and can be applied in the transportation sector [3]. Biogas produces a blue flame and has a heat value of between 4500 and $5000 * 4.184 \mathrm{~kJ} / \mathrm{m} 3$ with a methane content of $60-70 \%$ [4].

Biogas can be produced via the anaerobic digestion of various raw materials, such as animal manure, agricultural waste, sewage sludge, and food waste [5-7]. Among these waste streams, biogas production from agro-industrial residues is a favourable, cheap source that is environmentally sound and in line with the Waste to Wealth concept. Table 1 shows comparisons of biogas and methane yields that can be produced from different types of raw materials in relation to their methane compositions.

Table 1

Comparison of biogas, biomethane yield and methane content from different potential substrates.

\begin{tabular}{|c|c|c|c|c|}
\hline Feedstock & $\begin{array}{c}\text { Biogas yield } \\
\text { (mL/ gVS) }\end{array}$ & $\begin{array}{c}\text { Methane yield } \\
\left(\mathbf{m L ~ C H}_{4} / \mathbf{g V S}\right)\end{array}$ & $\begin{array}{c}\text { Methane content } \\
\text { (\%) }\end{array}$ & Reference \\
\hline Empty fruit bunch & - & $200-300$ & $40-50$ & {$[8]$} \\
\hline Food waste & 600 & 440 & $60-70$ & {$[9]$} \\
\hline Cattle manure & $400-450$ & $200-250$ & $49-55$ & {$[10,11]$} \\
\hline POME & 717 & $500-550$ & $65-75$ & {$[8,11]$} \\
\hline Swine manure & $400-450$ & $250-350$ & 65 & {$[12]$} \\
\hline Vegetable waste & 450 & $190-400$ & 65 & {$[13]$} \\
\hline
\end{tabular}

The utilisation of palm oil mill effluent (POME) as a feedstock has gained the interest of researchers to control waste production in agricultural sector derives from the palm oil industry. Palm oil 
plantations can be found abundantly in Southeast Asian countries, such as Indonesia, Malaysia, and Thailand, which produced approximately 36,21 , and 2 million*103 $\mathrm{kg}$ of palm oil, respectively, in 2017 [14]. Fig. 1 shows the world palm oil production in 2017 and highlights the significant contribution of Southeast Asian countries in the production of palm oil.

The use of POME as a source for biogas, especially in developing countries, positively impacts the economy and environment. However, it is necessary to find the most suitable and efficient method to enhance biogas production by implementing pretreatment processes during the upstream process and using appropriate bioreactors during the downstream process. Recommended pretreatment processes and reactor types for POME are summarised in Table 2. This review presents and discusses the advantages and disadvantages of recently developed pretreatment technologies and bioreactors that have been deemed suitable for enhancing biogas production from POME.

Top palm oil producer in Southeast Asia
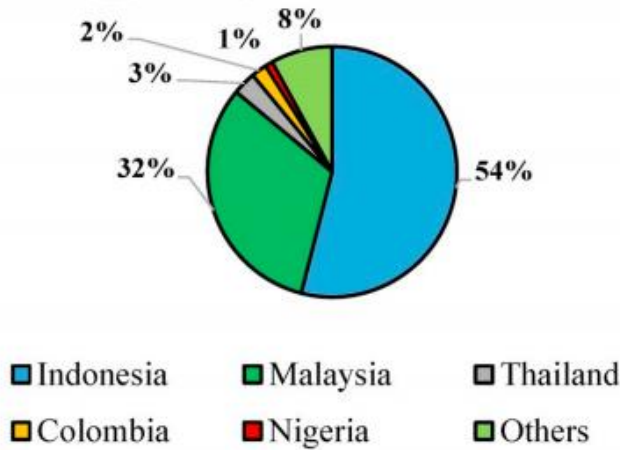

Fig. 1. Percentage of palm oil production from the top countries [14].

\section{Biogas production from POME}

If pivotal components such as carbohydrates, proteins, fats, cellulose, and hemicellulose are present, biomass may be utilised as a feedstock for biogas production. POME, which is rich in carbohydrates, proteins, and lipids, is considered one of the most suitable forms of biomass to be used in the production of biogas. POME can also be converted into biodiesel, biobutanol, biohydrogen, and polymers; can be a potential resource for algae-based biorefineries; and can be used in compost production due to its unique properties [25]. Table 3 outlines the physicochemical characteristics of POME.

An amount of $2.5 * 103 \mathrm{~kg}$ of POME can be generated during the production of one tonne of crude palm oil, resulting in the production of approximately $70 \mathrm{~m} 3$ biogas [28]. Accordingly, one tonne of POME can produce $28.13 \mathrm{~m} 3$ biogas. According to Sridhar and Adeoluwa [29], $1 \mathrm{~m} 3$ of biogas can generate $1.8 * 3.6 \mathrm{MJ}$ energy, corresponding to a power generation efficiency of $25 \%$. Without appropriate storage and treatment, however, biogas production from POME will disrupt the biogeochemical cycle and discharge large amounts of $\mathrm{CH} 4$ into the atmosphere. According to Gozan et al. [30], methanogenic reactions from POME components could produce more than $0.8 \mathrm{~L} / \mathrm{g}$ biogas with a methane concentration of above $50 \%$. Table 4 shows the reaction mechanisms of the components that exist in POME in relation to their biogas production and methane content. Biogas production from POME involves an anaerobic digestion process, which is a complex mechanism conducted through interactions among microorganisms. The process can be divided into four stages, namely, hydrolysis, acidogenesis, acetogenesis, and methanogenesis. Hydrolysis involves the breakdown of carbohydrates, lipids, and proteins into smaller molecules of sugar, long chain fatty acids, and amino acids, respectively. This process is conducted by a group of hydrolytic bacteria, such as Clostridium and Bacillus [31]. Hydrolysis converts all raw materials into amenable forms so that further microbial activities can occur. The hydrolysed compounds are taken up by acidogenic bacteria, such as Syntrophomonas, Pseudomonas, and Flavobacterium, to form intermediary 
compounds (i.e., alcohols; aldehydes; and volatile fatty acids, such as butyric, propanoic, and acetic acids) [32].

During acetogenesis, the intermediaries undergo degradation to form acetate, carbon dioxide, and hydrogen, which are produced by acetogenic bacteria, such as Desulfovibrio and Clostridium [33]. The final stage is methanogenesis, which involves two different groups of bacteria, namely, acetotrophic and hydrogenotrophic bacteria. Acetotrophic methanogens (Equation (2.1)) split acetate into methane and carbon dioxide, while hydrogenotrophic methanogens (Equation (2.2)) use hydrogen to form methane [34]. These reaction processes can be further explained as follows [35]:

$$
\begin{aligned}
& \mathrm{CH}_{3} \mathrm{COO}^{-}+\mathrm{H}_{2} \mathrm{O} \mathrm{CH}+\mathrm{HCO}_{3}^{-} \\
& 4 \mathrm{H}_{2}+\mathrm{HCO}_{3}^{-}+\mathrm{H}^{+} \mathrm{CH}_{4}+3 \mathrm{H}_{2} \mathrm{O}
\end{aligned}
$$

\section{Table 2}

Summary of pretreatment and bioreactor used for production of biogas by using POME as a raw

\begin{tabular}{|c|c|c|c|c|c|c|}
\hline \multirow[t]{2}{*}{ Year } & \multirow[t]{2}{*}{ Title } & \multicolumn{2}{|c|}{ Condition } & \multirow{2}{*}{$\begin{array}{c}\text { Pre- } \\
\text { treatment }\end{array}$} & \multirow{2}{*}{$\begin{array}{c}\text { Bio- } \\
\text { reactor }\end{array}$} & \multirow[t]{2}{*}{ Reference } \\
\hline & & $\mathbf{M}$ & $\mathbf{T}$ & & & \\
\hline 2008 & $\begin{array}{l}\text { Startup and operation of anaerobic EGSB reactor treating palm oil mill } \\
\text { effluent }\end{array}$ & 7 & $\mathrm{X}$ & NA & EGSB & [15] \\
\hline 2009 & $\begin{array}{l}\text { Effect of microwave and ultrasonic pretreatments on biogas production from } \\
\text { anaerobic digestion of Palm Oil Mill Effluent }\end{array}$ & $/$ & $\mathrm{X}$ & $\begin{array}{l}\text { - Microwave } \\
\text { - Ultrasonic }\end{array}$ & $\begin{array}{l}\text { Batch } \\
\text { reactor }\end{array}$ & [16] \\
\hline 2010 & $\begin{array}{l}\text { Biomethanation of Palm Oil Mill Effluent (POME) with a thermophilic } \\
\text { mixed culture cultivated using POME as a substrate }\end{array}$ & $\mathrm{X}$ & 1 & NA & CSTR & [17] \\
\hline 2011 & $\begin{array}{l}\text { Enhancing digestion efficiency of POME in anaerobic sequencing batch } \\
\text { reactor with ozonation pretreatment and cycle time reduction }\end{array}$ & 7 & $\mathrm{X}$ & Ozonation & ASBR & [18] \\
\hline 2012 & $\begin{array}{l}\text { Thermophilic anaerobic co-digestion of oil palm empty fruit bunches with } \\
\text { palm oil mill effluent for efficient biogas production }\end{array}$ & $\mathrm{X}$ & $/$ & tion & $\begin{array}{l}\text { Batch } \\
\text { reactor }\end{array}$ & [8] \\
\hline 2013 & Mesophilic co-digestion of palm oil mill effluent and empty fruit bunches & 1 & $\mathrm{X}$ & Co-digestion & CSTR & [19] \\
\hline 2014 & $\begin{array}{l}\text { Improvement of Biomethane Production Yield from Palm Oil Mill Effluent } \\
\text { using Ozonation Process }\end{array}$ & 7 & $\mathrm{X}$ & Ozonation & UASB & [20] \\
\hline 2015 & $\begin{array}{l}\text { An integrated method for Palm Oil Mill Effluent treatment for achieving zero } \\
\text { liquid discharge-A pilot study }\end{array}$ & $1 /$ & $\mathrm{X}$ & $\begin{array}{l}\text { Dissolve air } \\
\text { flotation }\end{array}$ & AnaEG & [21] \\
\hline 2016 & $\begin{array}{l}\text { Effect of chitosan on reactor performance and population of specific } \\
\text { methanogens in a modified CSTR treating raw POME }\end{array}$ & $\mathrm{X}$ & $/$ & Flocculation & CSTR & [22] \\
\hline 2017 & $\begin{array}{l}\text { Direct hydrolysis of palm oil mill effluent by xylanase enzyme to enhance } \\
\text { biogas production using two-steps thermophilic fermentation under non- } \\
\text { sterile condition }\end{array}$ & $\mathrm{X}$ & $/$ & $\begin{array}{l}\text { Enzymatic } \\
\text { hydrolysis }\end{array}$ & $\begin{array}{l}\text { Batch } \\
\text { reactor }\end{array}$ & [23] \\
\hline 2018 & $\begin{array}{l}\text { The use of acidified palm oil mill effluent for thermophilic biomethane } \\
\text { production by changing the hydraulic retention time in anaerobic sequencing } \\
\text { batch reactor }\end{array}$ & $\mathrm{X}$ & $/$ & $\begin{array}{l}\text { Acidified } \\
\text { POME }\end{array}$ & ASBR & [24] \\
\hline
\end{tabular}
material.

\section{*M- Mesophilic}

*T- Thermophilic

*NA- Data not available

During this process, $70 \%$ of the methane is formed by the acetotrophic methanogens pathway (Equation (2.1)), while $30 \%$ of the methane is produced through the hydrogenotrophic methanogens pathway (Equation (2.2)) [36].

The time needed for biogas production heavily depends on the temperature. According to Wang [37], at a mesophilic temperature, 30-40 days are required to complete the anaerobic digestion process. Meanwhile, at a thermophilic temperature, only 7-14 days are required for the entire process to occur.

According to Fountoulakis et al. [37], pH also plays an important role in the digestion process, especially during the acidogenic and methanogenic stages. Acidogenic sustains at $\mathrm{pH} 5$, while methanogenic requires a $\mathrm{pH}$ within the range of 6.5-7.2. Therefore, the suggested optimum $\mathrm{pH}$ range for the digestion process is $6.8-7.4$, as both bacterial groups can function efficiently within this range $[38,39]$. $\mathrm{pH}$ and alkalinity correlate to one another, as alkalinity helps to control the desired $\mathrm{pH}$ in the anaerobic digester. $\mathrm{pH}$ is a measure of hydrogen ion concentration, while alkalinity represents the capability of a substance to neutralise hydrogen ions. Increasing alkalinity at the beginning of the digestion process results in a reduction of volatile solids (VS) and biodegradation time, which 
enhances biogas production when compared with the reactors to which no alkaline additives (e.g., anhydrous ammonia, potassium bicarbonate, potassium carbonate, sodium bicarbonate, and sodium nitrate) have been added [40].

It was found that an alkalinity to chemical oxygen demand (COD) concentration ratio $(\mathrm{w} / \mathrm{w})$ of $1.2-$ 1.6 is sufficient to maintain a $\mathrm{pH}$ value of around 6.6 during the anaerobic digestion of carbohydrate waste to produce methane [41]. According to Labatut and Gooch [42], addition of calcium carbonate as much as $5500 \mathrm{mg} / \mathrm{L}$ helps to provide enough buffering capacity to withstand moderate shock loads of volatile fatty acids while maintaining a $\mathrm{pH}$ value of 7.4 , which is favourable for methanogenic bacteria. In addition to environmental factors, the pretreatment and configuration of bioreactors are boost biogas production from POME.

Table 3

Physicochemical characteristics and composition of raw POME $[25,26]$.

\begin{tabular}{|c|c|}
\hline Parameters & Concentrations \\
\hline \multicolumn{2}{|c|}{ General characteristic } \\
\hline Chemical oxygen demand $(\mathrm{mg} / \mathrm{L})$ & $15000-100000$ \\
\hline Biochemical oxygen demand (mg/L) & $10250-43750$ \\
\hline Total solid (mg/L) & $11500-79000$ \\
\hline Total suspended solid (mg/L) & $5000-54000$ \\
\hline Total volatile solid $(\mathrm{mg} / \mathrm{L})$ & $9000-72000$ \\
\hline Total nitrogen $(\mathrm{mg} / \mathrm{L})$ & $180-1400$ \\
\hline Oil and grease $(\mathrm{mg} / \mathrm{L})$ & $130-18000$ \\
\hline Temperature $(\stackrel{\circ}{ } \mathrm{C})$ & $80-90$ \\
\hline $\mathrm{pH}$ & $3.4-5.2$ \\
\hline Lignin (ppm) & 4700 \\
\hline Phenolics (ppm) & 5800 \\
\hline Pectin (ppm) & 3400 \\
\hline Carotene (ppm) & 8 \\
\hline \multicolumn{2}{|c|}{ Multielement } \\
\hline Cadmium, Cd (mg/L) & $0.01-0.02$ \\
\hline Calcium, Ca (mg/L) & $276-405$ \\
\hline Chromium, $\mathrm{Cr}$ (mg/L) & $0.05-0.43$ \\
\hline Copper, Cu (mg/L) & $0.8-1.6$ \\
\hline Cobalt, Co (mg/L) & $0.04-0.06$ \\
\hline Iron, $\mathrm{Fe}(\mathrm{mg} / \mathrm{L})$ & $75-164$ \\
\hline Magnesium, $\mathrm{Mg}(\mathrm{mg} / \mathrm{L})$ & $254-344$ \\
\hline Manganese, Mn (mg/L) & $2.1-4.4$ \\
\hline Phosphorus, $\mathrm{P}$ (mg/L) & $94-131$ \\
\hline
\end{tabular}




\begin{tabular}{|c|c|}
\hline Potassium, $\mathrm{K}$ (mg/L) & $1281-1928$ \\
\hline Zinc, Zn (mg/L) & $1.2-1.8$ \\
\hline \multicolumn{2}{|c|}{ Amino acid (g/100 g Protein) } \\
\hline Alanine (g) & 7.70 \\
\hline Arginine $(\mathrm{g})$ & 4.15 \\
\hline Aspartic Acid (g) & 9.66 \\
\hline Cystine (g) & 3.37 \\
\hline Glutamic acid (g) & 10.88 \\
\hline Glycine (g) & 9.43 \\
\hline Histidine (g) & 1.43 \\
\hline Isoleucine (g) & 4.53 \\
\hline Leucine $(\mathrm{g})$ & 6.86 \\
\hline Lysine (g) & 5.66 \\
\hline Methionine (g) & 6.88 \\
\hline Phenylalanine (g) & 3.20 \\
\hline Proline (g) & 4.57 \\
\hline Serine $(g)$ & 6.86 \\
\hline Threonine (g) & 2.58 \\
\hline Tyrosine (g) & 3.26 \\
\hline Tryptophan (g) & 1.26 \\
\hline Valine (g) & 3.56 \\
\hline \multicolumn{2}{|c|}{ Fatty acid (g/100 g Lipid) } \\
\hline Arachidic acid (g) & 7.56 \\
\hline Arachidonic acid (g) & 1.12 \\
\hline Behenic acid (g) & 2.62 \\
\hline Capric acid (g) & 4.29 \\
\hline Eicosapentaeoic acid (g) & 0.36 \\
\hline Eicosatrienoic acid (g) & 1.49 \\
\hline Heptadecanoic acid (g) & 1.39 \\
\hline 10-heptadecanoic acid (g) & 1.12 \\
\hline Lauric acid (g) & 9.22 \\
\hline Linoleic acid (g) & 4.72 \\
\hline Linolenic acid (g) & 4.72 \\
\hline
\end{tabular}




\begin{tabular}{|c|c|}
\hline Myristic acid (g) & 12.66 \\
\hline Oleic acid (g) & 8.54 \\
\hline Palmitic acid (g) & 14.45 \\
\hline Stearic acid (g) & 11.41 \\
\hline
\end{tabular}

3. Pretreatment process of POME to enhance biogas production

Raw materials that have not been pretreated require a longer processing time than pretreated raw materials. The type of pretreatment process to be used depends on the type of substrate being used for biogas production. As a lignocellulosic material, POME needs to be properly treated prior to being used for biogas production. The purpose of pretreatment is to make the raw materials consumable by microbial groups, which, in turn, increase the rate of reaction in anaerobic digestion and eventually boost biogas production. The pretreatment process (Fig. 2) acts as a catalyst that speeds up the reaction process. Theoretically, many types of pretreatments exist for treating lignocellulosic materials. However, not all pretreatment methods can be used to treat POME. Thorough research needs to be conducted to explore suitable and effective pretreatments for POME that could result in a high digestion rate and biogas yield. The following sections describe existing pretreatment techniques used for POME to increase biogas production.

Table 4

Potential biogas production from carbohydrates, proteins and lipids available inside POME [25,29].

\begin{tabular}{|c|l|c|c|}
\hline $\begin{array}{c}\text { Main } \\
\text { components }\end{array}$ & \multicolumn{1}{|c|}{ Methanogenic mechanisms } & $\begin{array}{c}\text { Biogas } \\
\text { production } \\
\text { (L/g) }\end{array}$ & $\begin{array}{c}\text { Methane } \\
\text { content } \\
\text { (\%) }\end{array}$ \\
\hline Carbohydrate & $\mathrm{C}_{6} \mathrm{H}_{10} \mathrm{O}_{5}+\mathrm{H}_{2} \mathrm{O} \rightarrow 3 \mathrm{CH}_{4}+3 \mathrm{CO}_{2}$ & 0.830 & 50.0 \\
\hline Protein & $\begin{array}{l}\mathrm{C}_{16} \mathrm{H}_{24} \mathrm{O}_{5} \mathrm{~N}_{4}+14.5 \mathrm{H}_{2} \mathrm{O} \rightarrow 8.25 \mathrm{CH}_{4}+3.75 \mathrm{CO}_{2}+4 \mathrm{NH}_{4}^{+} \\
+4 \mathrm{HCO}_{3-}\end{array}$ & 0.921 & 68.8 \\
\hline Lipid & $\mathrm{C}_{50} \mathrm{H}_{90} \mathrm{O}_{6}+24.5 \mathrm{H}_{2} \mathrm{O} \rightarrow 34.75 \mathrm{CH}_{4}+15.25 \mathrm{CO}_{2}$ & 1.425 & 69.5 \\
\hline
\end{tabular}

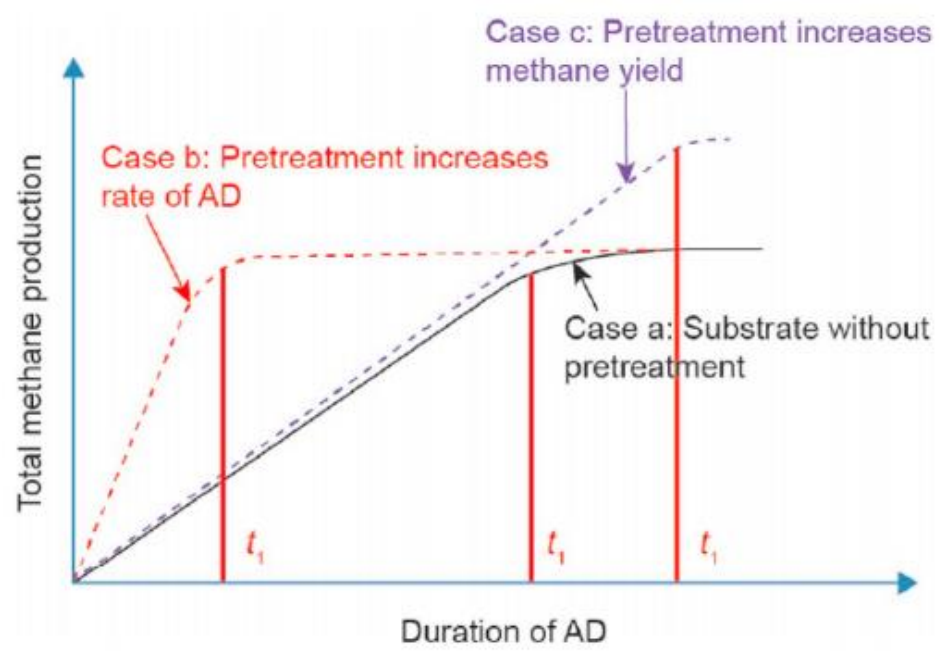

Fig. 2. Rate of digestion and methane production with and without pretreatment [43].

\subsection{Using acidified POME}

Acidified POME is produced during the biohythane process (Fig. 3). Biohythane, which consists of hydrogen and methane, is produced via a two-stage fermentation process. The first stage consists of 
hydrolysis and acidogenesis reactions, while the second stage involves acetogenesis and methanogenesis. Based on a previous report, the optimum $\mathrm{pH}$ range for the first stage is $5-6$, with a hydraulic retention time (HRT) of 1-3 days [44]. Meanwhile, the second stage requires a HRT of 1015 days with a $\mathrm{pH}$ of $7-8$, as this is a favourable $\mathrm{pH}$ for methanogenic bacteria [44]. During the first stage, POME is used to produce hydrogen, and the digestate formed is acidified POME, which has a high content of volatile fatty acids, such as butyrate and acetate [45]. The acidified POME is used as a substrate to produce methane and has been shown to produce high volumes of biogas [46-48].

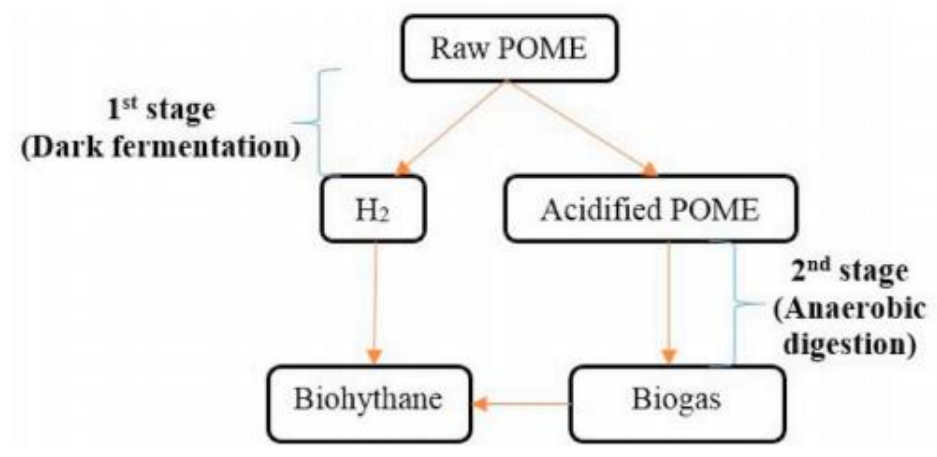

Fig. 3. Schematic diagram of biogas production from acidified POME.

However, the amount of biogas produced varies based on the type of bioreactor used. Krishnan et al. [47] used a continuous stirred tank reactor (CSTR) using an HRT of 5 days and produced $320 \mathrm{~L} \mathrm{CH} 4 / \mathrm{kg}$ chemical oxygen demand (COD), in which $94 \%$ of COD is removed from the acidified POME.

Meanwhile, in a study conducted by Mamimin et al. [49] using up-flow anaerobic sludge blanket (UASB) reactors, $315 \mathrm{~L} \mathrm{CH} 4 / \mathrm{kgCOD}$ was produced for a methane yield with $95 \%$ COD removal using an HRT of 6 days. Recent research by Nasir et al. [24], which used an anaerobic sequencing batch reactor (ASBR), shows that the lowest amount of methane produced was $260.3 \mathrm{~L} \mathrm{CH} 4 / \mathrm{kgCOD}$, which occurred when the HRT was 3 days. Only 71\% COD was removed in this case. Therefore, the use of an appropriate bioreactor and an adequate HRT impact the amount of biogas that can be produced from acidified POME.

\subsection{Addition of ash}

Ash is a waste product that is widely used in the wastewater treatment, construction and building industries as well as in anaerobic digestion processes. Adding ash during the digestion process increases the efficiency of volatile solid degradation, which, in turn, significantly enhances biogas production [50]. Ash acts as a co-enzyme, as it helps to reduce acidity in the anaerobic digestion process and enhance the microbial growth rate [51]. Lo et al. [52] added fly ash during the anaerobic digestion of municipal solid waste (MSW) and achieved a higher biogas rate ( $6.5 \mathrm{~L}$ day $1 \mathrm{~kg} 1 \mathrm{VS}$ ) when compared with the digestion of MSW without fly ash ( 4 L day $1 \mathrm{~kg} 1 \mathrm{VS})$. The use of ash in POME treatment removes heavy matter, oil, and grease [27]. Kutty et al. [53] used microwave incinerated rice husk ash (MIRHA) to remove zinc (Zn), copper (Cu), and COD from POME. As reported by Jijai et al. [54], adding biomass ash from rubber plantations and oil palm residues to POME produced $218.79 \mathrm{~L} \mathrm{CH} 4 / \mathrm{kgCOD}$, while POME without pretreatment produced only $103.15 \mathrm{~L}$ $\mathrm{CH} 4 / \mathrm{kgCOD}$. This indicates that, when added to POME, ash acts as a supplementary nutrition source and could be used as a cheap material for $\mathrm{pH}$ adjustment to enhance the biogas production process [55]. Fig. 4 is a schematic diagram representing the effects of adding ash prior to the anaerobic digestion process.

\subsection{Co-digestion}

Anaerobic co-digestion (Fig. 5) is defined as the combination of two or more different substrates during the digestion process to improve biogas production when the mono-digestion process is 
difficult to achieve [56]. As discussed by Mata-Alvarez et al. [57], the mono-digestion process has limitations in certain scenarios:

- Animal manure has a low organic content but high nitrogen $(N)$ concentration, which could inhibit the methanogenic process.

- Agro-industrial and lignocellulosic wastes are seasonal substrates with low $\mathrm{N}$ content.

- Municipal solid waste contains a high concentration of heavy metals.

- Sewage sludge has low organic loads.

\section{Raw POME + Ash}

\section{Anaerobic digestion}

\section{Biogas}

Fig. 4. Schematic diagram of ash addition prior to anaerobic digestion process.

$$
\text { Raw POME + Different substrates }
$$

\section{Anaerobic co-digestion}

\section{Biogas}

Fig. 5. Biogas production from co-digestion process.

The implementation of a co-digestion process could rectify these limitations. To date, various types of substrates, as well as the codigestion of POME with other substrates, have been tested by researchers to obtain high methane production. It has been reported that the co-digestion of POME with animal manure significantly improves biogas production, as manure provides a buffering capacity and a wide range of nutrients, while the addition of POME, which is rich in carbon, balances the carbon-to-nitrogen $(\mathrm{C} / \mathrm{N})$ ratio of the feedstock and reduces ammonia inhibitors, which hinder the digestion process [58].

Sidik et al. [10] reported that the co-digestion of POME with cow manure at a 70:30 ratio under mesophilic conditions could produce methane content of $61.13 \%$ over 21 days of experimentation. Similar findings also revealed that a 70:30 ratio of POME to cow manure could produce a methane content of 35.35\% over 28 days of digestion [59]. POME has also been co-digested with other feedstock, such as empty fruit bunch (EFB), decanter cake, rumen fluid, and refined glycerine wash water [60-63].

\subsection{Coagulation-flocculation}

A coagulation-flocculation (CF) process is defined as the addition of a coagulant/flocculent to assist solid-liquid separation. The addition of a coagulant helps to trap solid particles in the wastewater agglomerate, and the addition of a flocculent leads to the formation of bigger flocs. Sludge-rich volatile solids (VS) that are produced after the sedimentation process can be directly used for the anaerobic digestion process, shown in Fig. 6. 


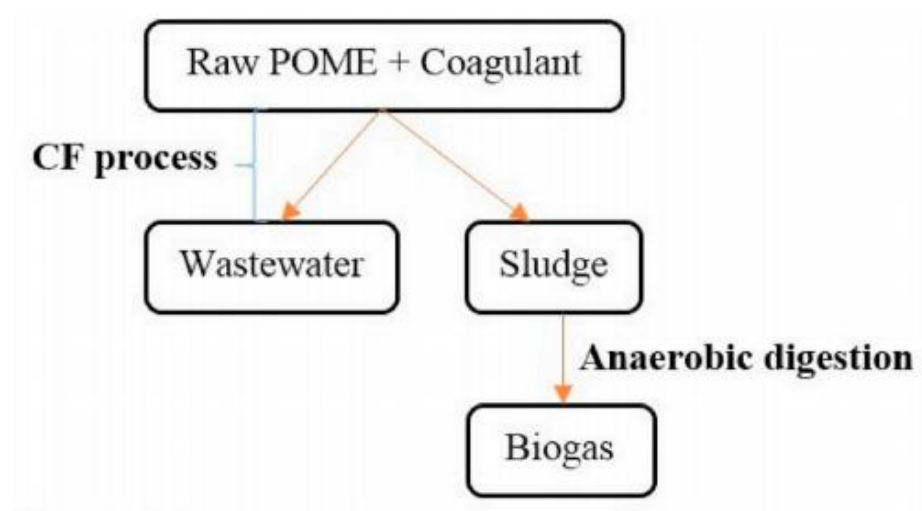

Fig. 6. Use of a CF process prior to an anaerobic digestion process.

For POME digestion, sludge is typically not granulated, which means it takes a longer time to complete the start-up period. Khemkhao et al. [64] used chitosan as a coagulant in POME treatment. The results show that chitosan is a viable sludge granulator and could shorten the start-up period in UASB systems. Therefore, the addition of a coagulant helps to enhance sludge granulation and increase the biogas yield. In addition, coagulation also contributes to the accumulation of VS. Observations from a jar test showed that chitosan adheres to the suspended biomass and enhanced flocculation, which helps the working microorganisms to aggregate together, thus preventing them from being washed out from the digester [22].

\subsection{De-oiling}

Conventionally, POME is treated using a ponding system consisting of a de-oiling tank and acidification, anaerobic and aerobic, or facultative ponds [65]. The purpose of the de-oiling tank is to remove oil and floating fats from the POME prior to further treatment (Fig. 7). The de-oiling process can be conducted using a flotation system, coagulation-flocculation process, and an adsorption process using activated carbon, zeolite, and bentonite [66-68]. De-oiled POME is a thin, brown liquid with high volatile fatty acid (VFA) content of around $0.006-0.008 \mathrm{~kg} / \mathrm{L}$ and a low lipid content of $0.002-0.003 \mathrm{~kg} / \mathrm{L}$. A previous study investigated the efficiency of raw and de-oiled POME in batch assay continuous reactor experiments using up-flow anaerobic sludge blanket (UASB) and expanded granular sludge bed (EGSB) reactors for biogas production [69]. The results show that de-oiled POME had a higher methane yield in the batch assay ( $610 \mathrm{~L} \mathrm{CH} 4 / \mathrm{kgVS})$, UASB ( $600 \mathrm{~L} \mathrm{CH} 4 / \mathrm{kgVS})$, and EGSB ( $555 \mathrm{~L} \mathrm{CH} 4 / \mathrm{kgVS}$ ) than raw POME (batch assay $1 / 4503 \mathrm{~L} \mathrm{CH} 4 / \mathrm{kgVS}$; UASB $1 / 4436 \mathrm{~L} \mathrm{CH} 4 / \mathrm{kgVS}$; EGSB $1 / 4$ $438 \mathrm{~L} \mathrm{CH} 4 / \mathrm{kgVS}$ ). According to Fang et al. [69], the anaerobic digestion of de-oiled POME has a higher methane yield than that of raw POME due to the lower portion of biofibres, which are more recalcitrant than the rest of organic matter in POME.

\subsection{Dissolved air flotation}

Dissolved air flotation (DAF) has been extensively used prior to the anaerobic digestion process in industrial effluent treatments, such as in abattoir and municipal wastewater treatments $[70,71]$. A DAF process can be defined as a process of solid-liquid separation that aims to produce potable water by using air bubble flotation. The removal of solid and liquid are accomplished by dissolving air in the saturator at high pressure and releasing saturated water into the flotation cell, where bubbles are formed due to the reduction in pressure. Bubbles and contaminants rise to the surface and form a floating bed of material, which is then removed by a surface skimmer and transported to a digestor [71].

Tabassum et al. [21] investigated the use of DAF for the pretreatment of POME prior to the anaerobic digestion process. This pilot-scale study was conducted over one year using an advanced anaerobic expanded granular sludge bed (AnaEG), bioreactor, and DAF pretreatment due to their ability in recuperative thickening. The findings show that $30 \mathrm{~m} 3$ biogas was produced with a COD removal rate 
of $93 \%$. In addition to the contribution of the bioreactor, recuperative thickening also led to a $25 \%$ increase in anaerobic digestion, which enhances biogas production [72]. However, the application of DAF in POME is still in its primary stages and requires further research on the provision of efficient treatments. Fig. 8 provides an overview of biogas production using DAF as a pretreatment method.

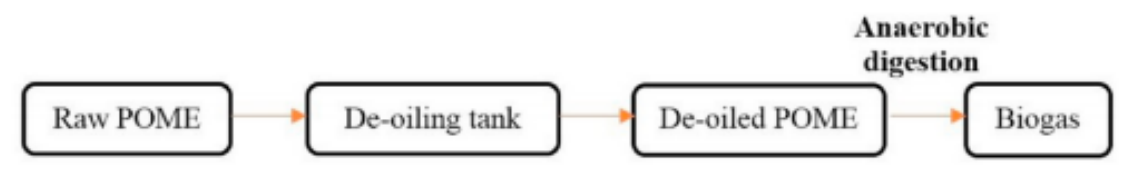

Fig. 7. De-oiled POME for higher biogas production.

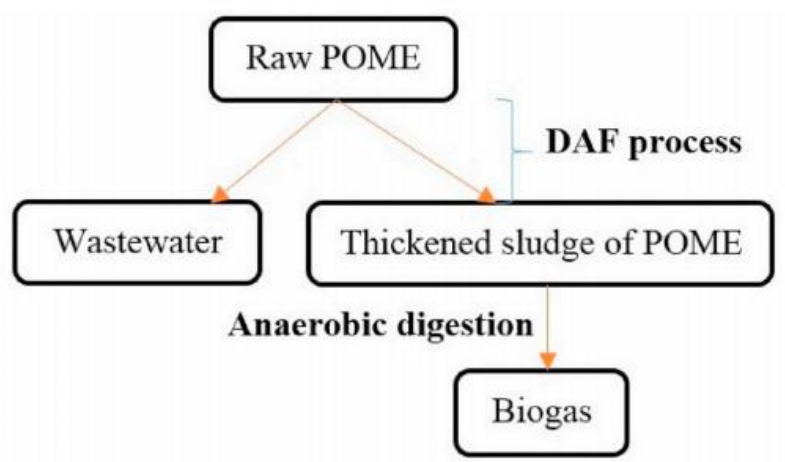

Fig. 8. Use of DAF to pretreat POME.

\subsection{Enzymatic hydrolysis}

Enzymatic hydrolysis is a rate-limiting step due to the involvement of a complex structure of cellulose, hemicellulose, and lignin. POME consists of $38.36 \%$ cellulose, $23.21 \%$ hemicellulose, and $26.72 \%$ lignin [73]. Due to the high lignin content, a pretreatment process is required to weaken and disrupt the matrix of lignocellulosic materials. Enzymatic pretreatment processes are more environmentally friendly than other pretreatment techniques.

However, the application of enzymes in a pretreatment process for biogas production is expensive. One way to overcome this limitation is to use locally produced enzymes [74]. According to Nomanbhay and Hussain [75], POME is composed of soluble and insoluble carbohydrates. Soluble carbohydrates have a low concentration $(0.0039 \mathrm{~kg} / \mathrm{L})$, while insoluble carbohydrates have a concentration of $0.026 \mathrm{~kg} / \mathrm{L}$ in POME. Insoluble carbohydrates consist of high molecular weight compounds, such as cellulose, hemicellulose, and starch. Therefore, it is important to hydrolyse the complex carbohydrates to obtain a high yield of fermentable sugar, thus leading to an increase in biogas production.

This has been shown to be effective in a study conducted by Prasertsan et al. [23], in which xylanase was used for the enzymatic hydrolysis of POME. It is reported that POME treated via enzymatic hydrolysis ( $914 \mathrm{~L} \mathrm{CH} 4 / \mathrm{kg}$ VS) yielded roughly three times more biomethane than POME without enzymatic hydrolysis (297 L CH4/kg VS). Cellulase and lipase have also been used to increase sugar reduction in POME $[76,77]$. Fig. 9 illustrates the conversion of POME into biogas by using enzymatic hydrolysis prior to the anaerobic digestion process.

\subsection{Microwave irradiation}

Fig. 10 shows the flow for the use of microwave irradiation in the biogas production of POME. Microwave irradiation is a widely used pretreatment method for agricultural residues due to its simplicity, low energy requirement, high heating capacity within a short period of time, minimum formation of inhibitors, and ability to degrade cellulose fractions [78].

Saifuddin and Fazlili [16] examined the effect of microwave irradiation on biogas production from POME. In this study, $58 \mathrm{~L} \mathrm{CH} 4 / \mathrm{kgCOD}$ was produced from $1 \mathrm{~L}$ of sludge after 3 min of microwave 
irradiation, with an energy consumption rate of $252 \mathrm{~kJ} / \mathrm{L}$ sludge. Meanwhile, POME without any pretreatment produced $37 \mathrm{~L} \mathrm{CH} 4 / \mathrm{kgCOD}$ from $1 \mathrm{~L}$ of sludge. Using microwave irradiation during pretreatment could also accelerate enzymatic reactions. It has been reported that the enzymatic hydrolysis of POME produced only $0.0238 \mathrm{~kg} / \mathrm{L}$ of reducing sugar, while microwave-irradiationassisted enzymatic hydrolysis yielded a higher amount of sugar reduction $(0.0383 \mathrm{~kg} / \mathrm{L})$ [75]. Although the use of lab-scale microwave irradiation pretreatment has significantly improved biogas production, its industrial-scale use is unlikely due to its high cost.

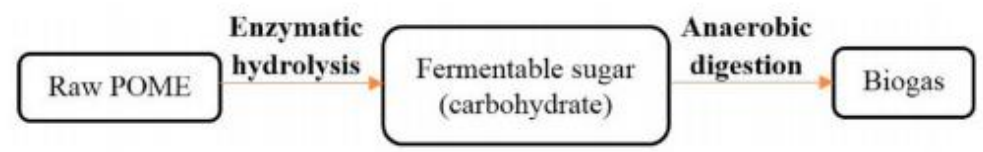

Fig. 9. Overview of enzymatic hydrolysis to increase biogas productions from POME.

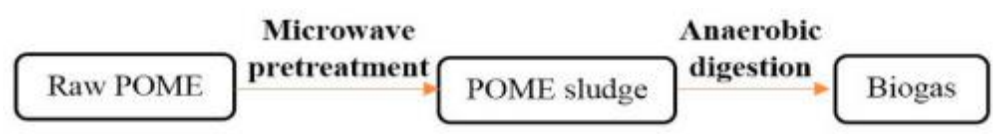

Fig. 10. Pretreatment of POME using microwave to increase biogas production.

3.9. Immobilisation media

Immobilisation media are defined as a wide variety of cells, particle attachments, or entrapments that are immobilised by using support materials known as carriers [79]. Immobilisation media are added to a bioreactor with raw POME (Fig. 11) to maximise the growth rate of micro-organisms, thus minimising the inhibiting effect of toxic pollutants and reducing HRT [80]. Previously, zeolite and cement kiln dust were found to act as immobilisation media used for the anaerobic digestion of POME $[81,82]$. Zeolite is a natural mineral with a large surface area that contains several essential minerals required for the growth of anaerobic microbes, such as potassium and iron [81]. Meanwhile, cement kiln dust (CKD) is a by-product of the cement manufacturing process and is used as a buffering agent in the anaerobic digestion of POME [82].

Ramadhani et al. [83] applied zeolite as microbial immobilisation media in POME, and 1.949 L of methane was produced within 14 days. However, since a small amount of zeolite provides insufficient space for the immobilisation of bacteria and because an excess dosage could disrupt microbes' nutrient intake, an appropriate amount of zeolite must be added to POME [84]. It is reported that POME with CKD removed $95 \%$ of COD with a methane yield of $650 \mathrm{~L} \mathrm{CH} 4 / \mathrm{kgCOD}$, while POME without CKD removed only $10.5 \%$ of COD and resulted in a methane yield of $130 \mathrm{~L} \mathrm{CH} 4 / \mathrm{kgCOD}$ [85].

\subsection{Ozonation}

Ozonation is a chemical pretreatment process that has gained the interest of researchers due to its rapid biodegradability capacity. Ozone has been widely applied in sewage sludge treatments to degrade the organic and cell growth to improve performance in subsequent anaerobic digestion [86]. Ozone is one of the strongest oxidising agents (EO $1 / 42.07 \mathrm{~V}, 25 \mathrm{C})$, is soluble in water $(110 \mathrm{mg} / \mathrm{L}, 25 \mathrm{C})$, and is ready to use after its production from oxygen in strongly endothermic reactions [87].

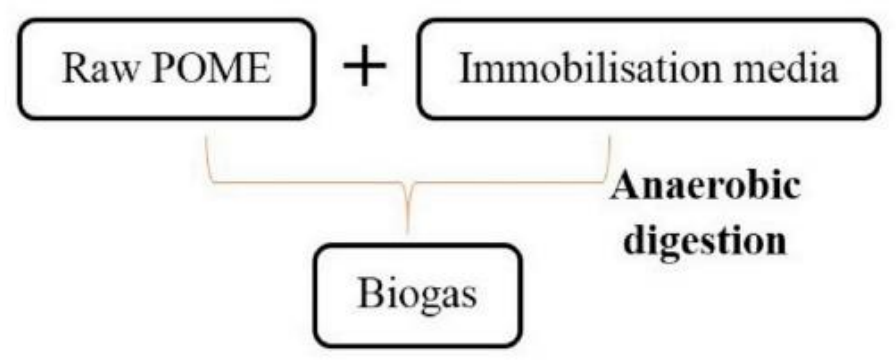


Fig. 11. Addition of immobilisation media during pretreatment for the biogas production of POME.

According to Elliot and Mahmood [88], ozone reacts with polysaccharides, proteins, and lipids and transforms them into smaller compounds. The use of ozonation as a pretreatment method for the anaerobic digestion of POME was investigated by Tanikkula et al. [20]. An experiment was conducted in a batch reactor in which POME that was pretreated by ozonation produced $273.8 \mathrm{~L} \mathrm{CH} 4 / \mathrm{kgCOD}$ of methane, while raw POME without ozonation produced $177.9 \mathrm{~L} \mathrm{CH} / \mathrm{kgCOD}$. In another study by Chaiprapat and Laklam [18], ASBR was used as a digester and produced $410 \mathrm{~L} \mathrm{CH} 4 / \mathrm{kgCOD}$ of methane (64.1\% methane content) and achieved $64.2 \%$ COD removal.

Ozonation is undeniably an effective pretreatment method, but the implementation of a full-scale ozonation plant would consume up to six times more energy than that which can be recovered from the combustion of the produced methane [89]. Fig. 12 illustrates a general overview of the pretreatment of POME using ozonation.

\subsection{Ultrasonication}

Ultrasonication (Fig. 13) is a promising and effective mechanical pretreatment method for enhancing sludge biodegradability by disrupting the physical, chemical, and biological properties of sludge. Ultrasonication has been used widely in the anaerobic digestion of waste activated sludge (WAS). However, few investigations have been conducted on its effectiveness as a pretreatment method for the anaerobic digestion of POME [90-92].

The purpose of ultrasonic pretreatment is to release intracellular materials by destroying their cell walls, disintegrating sludge flocs, and breaking large organic particles into smaller particles $[93,94]$. In ultrasonic hydrolysis, a small particle size is one of the key parameters in the pretreatment process, as it increases the lignocellulosic surface area and enhances the accessibility of the enzyme [95]. The application of ultrasonic pretreatment for POME led to a $16 \%$ increase in biogas production by using settings of $20 \mathrm{kHz}$ and $100 \mathrm{~W}$ [16]. It was reported that POME that underwent ultrasonic pretreatment prior to anaerobic digestion yielded $44 \mathrm{~L} \mathrm{CH} 4 / \mathrm{kgCOD}$, while untreated POME only yielded $37 \mathrm{~L} \mathrm{CH} 4 / \mathrm{kgCOD}$. Table 5 summarises the available pretreatment techniques for POME that increase biogas production.

\section{Raw POME}

\section{Ozonolysis (reduce lignin content)}

\section{Pretreated POME}

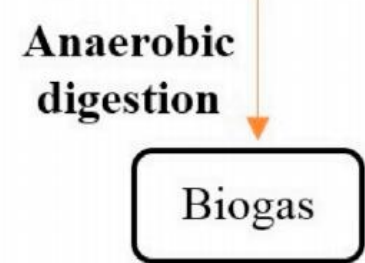

Fig. 12. Overview of the ozonation process prior to the anaerobic digestion process.

Ultra-

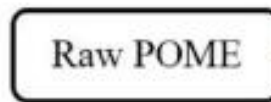
sonication

Fig. 13. Use of ultrasonication as a POME pretreatment method. 
4. Prominent anaerobic bioreactor

Bioreactors for treating POME have been extensively studied using various configurations of reactors, such as anaerobic fluidized bed reactors (AFBR), anaerobic sequencing batch reactors (ASBR), continuous stirred tank reactors (CSTR), expanded granular sludge beds (EGSB), upflow anaerobic filtration (UAF), up-flow anaerobic sludge blankets (UASB), and up-flow anaerobic sludge fixed-film (UASFF) reactors. These reactors have been shown to be effective in treating POME [27, 102].

Advances in bioprocess engineering have led to the development of digesters that can improve yields and efficiencies, such as advanced anaerobic expanded granular sludge beds (AnaEG), anaerobic membrane reactors (AnMBR) and up-flow anaerobic sludge blanket-hollow centred packed beds (UASB-HCPB). The utilisation of these reactors is still in its primary stages, and extensive studies are required to optimise their operational conditions and stability.

\subsection{Granular sludge bed}

AnaEG is a new reactor developed by Li et al. [103] for the treatment of coal gasification wastewater that combines the technological advantages of UASB and EGSB reactors. Hydrolysis and acidogenesis processes occur at the bottom section of the reactor, approximately $1 / 3$ of the sludge bed height while methanogenesis reaction takes place at the upper section. Accordingly, the effluent produced in the reactor does not need to be recycled into the influent in order to maintain a high upward velocity, and the wastewater flows in a plug flow pattern [103]. Meanwhile, organic matter is degraded by acidogenesis into a methanogenesis phase in an upward direction resulting in a twophase anaerobic digestion process that occurs in a single reactor.

As shown in Fig. 14, AnaEG can be divided into three sections: inlet, reactor, and gas-solid-liquid separation sections. Wastewater enters from the reactor base and degrades organic matter in an upward direction. In the end, the products formed (i.e., methane gas and organic acid) can be found in two separate layers inside the AnaEG reactor.

AnaEG has been implemented in industrial wastewater treatments, such as the starch processing of wastewater, including pharmaceutical and chemical wastewater [104]. Recently, the utilisation of an AnaEG reactor for the treatment of POME was researched. The results show that AnaEG has a substantial capacity for the anaerobic treatment of POME, as it can remove $93 \%$ COD and produce $57 \%$ methane from POME sludge [21]. It is estimated that each tonne of COD that is removed by an AnaEG reactor can produce $340 \mathrm{~m} 3$ biogas with an average composition of $65-70 \% \mathrm{CH} 4,25-30 \%$ $\mathrm{CO} 2$, and 200-1500 ppm H2S [105]. The sludge recovered from POME in an AnaEG reactor also has much potential to be used as a biofertilizer, as the material could enhance soil fertility beyond what is possible when using fertiliser acquired from raw POME and chicken manure [106].

\subsection{Anaerobic membrane}

Membrane technologies are being used commercially in industrial wastewater treatment processes. However, the use of membrane reactors in the biogas production of POME requires pilot-scale studies. To date, two types of membrane bioreactors exist: external cross flow and submerged membrane (Fig. 15). In external cross flow (Fig. 15a), the membrane is separated from the reactor, and the bioreactor broth is forced to the membrane module by a pump to permeate through the membrane [108]. In the submerged configuration (Fig. 15b), the membrane is directly submerged in the liquid inside the bioreactor or submerged in a separate container that is connected to the bioreactor [108]. The use of a submerged membrane requires less energy and space, but the process is prone to fouling due to high cell concentrations [109].

\section{Table 5}

Pretreatment used on POME to increase biogas production available in 2019.

\begin{tabular}{|l|l|l|l|l|}
\hline & & Operating condition & Research finding & \\
\hline
\end{tabular}




\begin{tabular}{|c|c|c|c|c|c|c|c|c|}
\hline $\begin{array}{c}\text { Pretreatme } \\
\text { nt }\end{array}$ & $\begin{array}{l}\text { Biorea } \\
\text { ctors }\end{array}$ & $\mathrm{pH}$ & $\begin{array}{l}\text { Temper- } \\
\text { ature } \\
\text { (으) }\end{array}$ & $\begin{array}{c}\text { HRT } \\
\text { (days) }\end{array}$ & $\begin{array}{c}\text { COD } \\
\text { removal } \\
(\%)\end{array}$ & $\begin{array}{c}\mathrm{CH}_{4} \\
\text { content } \\
\%\end{array}$ & $\mathrm{CH}_{4}$ yield & $\begin{array}{c}\text { Refe } \\
\text { renc } \\
\text { e }\end{array}$ \\
\hline $\begin{array}{l}\text { Acidified } \\
\text { POME }\end{array}$ & ASBR & $\begin{array}{c}7.0- \\
7.5\end{array}$ & 54 & 3 & 71 & 79.30 & $\begin{array}{c}260.3 \mathrm{~L} \\
\mathrm{CH}_{4} / \mathrm{kgCOD}\end{array}$ & [24] \\
\hline $\begin{array}{l}\text { Addition of } \\
\text { ash }\end{array}$ & $\begin{array}{l}\text { Batch } \\
\text { reacto } \\
r\end{array}$ & $\begin{array}{c}6.8- \\
7.2\end{array}$ & $28-30$ & $15-20$ & NA & $\begin{array}{l}62.0- \\
73.75\end{array}$ & $\begin{array}{c}218.79 \mathrm{~L} \\
\mathrm{CH}_{4} / \\
\mathrm{kgCOD}\end{array}$ & [47] \\
\hline \multicolumn{9}{|l|}{$\begin{array}{l}\text { Co- } \\
\text { digestion }\end{array}$} \\
\hline $\begin{array}{c}\text { Cow } \\
\text { manure }\end{array}$ & $\begin{array}{c}\text { Batch } \\
\text { reacto } \\
r\end{array}$ & $\begin{array}{c}6.8- \\
7.5\end{array}$ & $\begin{array}{l}M-35 \\
T-50\end{array}$ & 28 & $\begin{array}{l}\mathrm{M}-52.07 \\
\mathrm{~T}-77.01\end{array}$ & $\begin{array}{c}\mathrm{M}- \\
35.35 \\
\mathrm{~T}-46.16\end{array}$ & NA & [52] \\
\hline $\begin{array}{c}\text { Decanter } \\
\text { cake }\end{array}$ & $\begin{array}{l}\text { Batch } \\
\text { reacto } \\
r\end{array}$ & 7 & 60 & 45 & NA & 65.21 & $\begin{array}{c}391 \mathrm{~L} \\
\mathrm{CH}_{4} / \mathrm{kgVS}\end{array}$ & [55] \\
\hline $\begin{array}{l}\text { Empty fruit } \\
\text { bunch }\end{array}$ & $\begin{array}{l}\text { Batch } \\
\text { reacto } \\
r\end{array}$ & $\begin{array}{c}5.6- \\
8.0\end{array}$ & $27-30$ & 14 & 27 & 61.70 & $\begin{array}{c}0.5932 \mathrm{~L} \\
\mathrm{CH}_{4} / \mathrm{kgVS}\end{array}$ & [53] \\
\hline Microalgae & $\begin{array}{l}\text { Batch } \\
\text { reacto } \\
r\end{array}$ & $\begin{array}{c}7.4- \\
7.5\end{array}$ & 48 & 7 & 95 & NA & $\begin{array}{c}480 \mathrm{~L} \\
\mathrm{CH}_{4} / \mathrm{kgCOD}\end{array}$ & [87] \\
\hline $\begin{array}{c}\text { Poultry } \\
\text { manure + } \\
\text { Glycerin }\end{array}$ & $\begin{array}{l}\text { Batch } \\
\text { reacto } \\
r\end{array}$ & $\begin{array}{c}6.8- \\
7.2\end{array}$ & $\begin{array}{l}\text { Mesoph } \\
\text { ilic }\end{array}$ & 150 & 96 & NA & $\begin{array}{c}450 \mathrm{~L} \\
\mathrm{CH}_{4} / \mathrm{kgCOD}\end{array}$ & [88] \\
\hline $\begin{array}{c}\text { Refined } \\
\text { glycerin } \\
\text { wash water }\end{array}$ & CSTR & $\begin{array}{c}4.2- \\
5.7\end{array}$ & $\begin{array}{l}\text { Mesoph } \\
\text { ilic }\end{array}$ & 85 & 90 & NA & $\begin{array}{c}150 \mathrm{~L} \\
\mathrm{CH}_{4} / \mathrm{kgCOD}\end{array}$ & [56] \\
\hline $\begin{array}{l}\text { Rumen } \\
\text { fluid }\end{array}$ & $\begin{array}{l}\text { Semi } \\
\text { CSTR }\end{array}$ & 7.2 & 37 & 20 & 96.48 & 61.80 & NA & [54] \\
\hline $\begin{array}{l}\text { Sewage } \\
\text { sludge }\end{array}$ & $\begin{array}{c}\text { Batch } \\
\text { reacto } \\
r\end{array}$ & NA & 35 & 50 & NA & NA & $\begin{array}{c}456 \mathrm{~L} \\
\mathrm{CH}_{4} / \mathrm{kgVS}\end{array}$ & [89] \\
\hline $\begin{array}{l}\text { Skim latex } \\
\text { serum }\end{array}$ & $\begin{array}{l}\text { Batch } \\
\text { reacto } \\
r\end{array}$ & $\begin{array}{c}7.5- \\
7.8\end{array}$ & 55 & 90 & 85 & NA & $\begin{array}{c}311.2 \mathrm{~L} \\
\mathrm{CH}_{4} / \mathrm{kgVS}\end{array}$ & [90] \\
\hline \multicolumn{9}{|c|}{$\begin{array}{l}\text { Coagulation/Floccul } \\
\text { ation }\end{array}$} \\
\hline $\begin{array}{l}\text { Aluminium } \\
\text { sulphate }\end{array}$ & UASB & NA & $55-57$ & 2.4 & 81 & 76 & $\begin{array}{c}320 \mathrm{~L} \\
\mathrm{CH}_{4} / \mathrm{kgCOD}\end{array}$ & [91] \\
\hline $\begin{array}{l}\text { Cationic } \\
\text { and } \\
\text { anionic } \\
\text { polyacryla } \\
\text { mide }\end{array}$ & UASFF & NA & $35-38$ & 1.5 & 93 & NA & $\begin{array}{c}310 \mathrm{~L} \\
\mathrm{CH}_{4} / \mathrm{kgCOD}\end{array}$ & [92] \\
\hline Chitosan & $\begin{array}{l}\text { Modifi } \\
\text { ed } \\
\text { CSTR }\end{array}$ & 7.8 & $55-57$ & 3.3 & 74 & 68 & $\begin{array}{c}340 \mathrm{~L} \\
\mathrm{CH}_{4} / \mathrm{kgCOD}\end{array}$ & [22] \\
\hline $\begin{array}{l}\text { Deoiled } \\
\text { POME }\end{array}$ & $\begin{array}{l}\text { UASB } \\
\text { (U) }\end{array}$ & 6 & 55 & 5 & $\begin{array}{l}U-91.5 \\
E-92.3\end{array}$ & $\begin{array}{l}U-74 \\
E-73\end{array}$ & $\begin{array}{l}\mathrm{U}-600 \mathrm{~L} \\
\mathrm{CH} / \mathrm{kgVS}\end{array}$ & [62] \\
\hline
\end{tabular}




\begin{tabular}{|c|c|c|c|c|c|c|c|c|}
\hline & $\begin{array}{c}\text { EGSB } \\
(E)\end{array}$ & & & & & & $\begin{array}{l}\mathrm{E}-555 \mathrm{~L} \\
\mathrm{CH}_{4} / \mathrm{kgVS} \\
\end{array}$ & \\
\hline $\begin{array}{c}\text { Dissolve air } \\
\text { flotation }\end{array}$ & AnaEG & 7 & NA & NA & 93.7 & 57 & NA & [21] \\
\hline $\begin{array}{l}\text { Enzymatic } \\
\text { hydrolysis }\end{array}$ & $\begin{array}{c}\text { Batch } \\
\text { reacto } \\
r\end{array}$ & NA & 60 & 45 & 89.1 & 62.63 & $\begin{array}{c}914 \mathrm{~L} \\
\mathrm{CH}_{4} / \mathrm{kgVS}\end{array}$ & [23] \\
\hline Microwave & $\begin{array}{c}\text { Batch } \\
\text { reacto } \\
r\end{array}$ & 7.2 & $32-37$ & 15 & NA & NA & $\begin{array}{c}58 \mathrm{~L} \\
\mathrm{CH}_{4} / \mathrm{kgCOD}\end{array}$ & [16] \\
\hline \multicolumn{9}{|c|}{ Immobilisation media } \\
\hline $\begin{array}{l}\text { Natural } \\
\text { zeolite }\end{array}$ & AFBR & 7.0 & $\begin{array}{l}\text { Mesoph } \\
\text { ilic }\end{array}$ & 21 & NA & 63.16 & NA & [76] \\
\hline $\begin{array}{l}\text { Cement } \\
\text { kiln dust }\end{array}$ & UASB & 7.7 & 35 & 0.83 & 95 & NA & $\begin{array}{c}650 \mathrm{~L} \\
\mathrm{CH}_{4} / \mathrm{kgCOD}\end{array}$ & [78] \\
\hline Ozonation & ASBR & 7.2 & NA & 10 & 64.2 & 64.1 & $\begin{array}{c}410 \mathrm{~L} \\
\mathrm{CH}_{4} / \mathrm{kgCOD}\end{array}$ & [18] \\
\hline Ultrasonic & $\begin{array}{c}\text { Batch } \\
\text { reacto } \\
r\end{array}$ & 7.2 & $32-37$ & 15 & NA & NA & $\begin{array}{c}44 \mathrm{~L} \\
\mathrm{CH}_{4} / \mathrm{kgCOD}\end{array}$ & {$[16]$} \\
\hline
\end{tabular}

There are different treatment processes in membrane bioreactors, such as aerobic membrane bioreactors (AerMBRs), anaerobic membrane reactors (AnMBR), hybrid membrane bioreactors (HypMBR), sonication membrane bioreactors (SonMBR), and thermophilic and mesophilic membrane bioreactors (TheMBR) [110].

During the anaerobic digestion of POME, AnMBR is used to promote the ideal anaerobic conditions to produce biogas. Abdulrahman et al. [111] conducted a study on the performance of AnMBR as the digester to treat POME by using a cross flow ultra-filtration (CUF) membrane with an average pore size of $0.1 \mu \mathrm{m}$. The results show a significant amount of COD removal (96-99\%) and a methane yield of $250-270 \mathrm{~L} \mathrm{CH} 4 / \mathrm{kgCOD}$. Therefore, AnMBR is a useful alternative for treating industrial wastewater - especially POME - that also recovers a significant amount of methane.

A common issue related to the use of membrane bioreactors is biological fouling, which is significantly influenced by the presence of extracellular polymeric substances (EPSs) [112]. Hence, intense control strategies have been investigated to solve such problems [113-115]. A recent reliable method involves the implementation of nitrifying-enriched activated sludge (NAS), which results in lower EPS production and decreases the extent of fouling problems [116]. This method shows that the greater proportion of nitrifying bacteria can improve permeation flux and operation time for substantial nutrient removal efficiency in a cross-flow MBR, with less fouling. Thus, it is strongly recommended that this type of approach is used for high-strength wastewaters, such as POME. Despite the fouling issue, membrane bioreactors have a strong capability to remove nutrients that commonly trigger eutrophication, such as nitrogen and phosphorus. Oliveira et al. [117] reported the successful integration of MBR with an anaerobic main stream reactor (AMSR), by which $32 \%$ of sludge was removed from synthetic wastewater, reduced the membrane fouling tendency, and increased total nitrogen removal to up to $78 \%$. Furthermore, Ahmad et al. [118] observed the performance of a hybrid membrane bioreactor to treat raw POME. In this study, membrane fouling occurred due to cake resistance, which contributed to $74 \%$ of the total resistance. The system removed large percentages of COD (94\%) and suspended solids (98\%), while simultaneously reducing total nitrogen and total phosphorus content by as much as $83 \%$ and $64 \%$, respectively. 


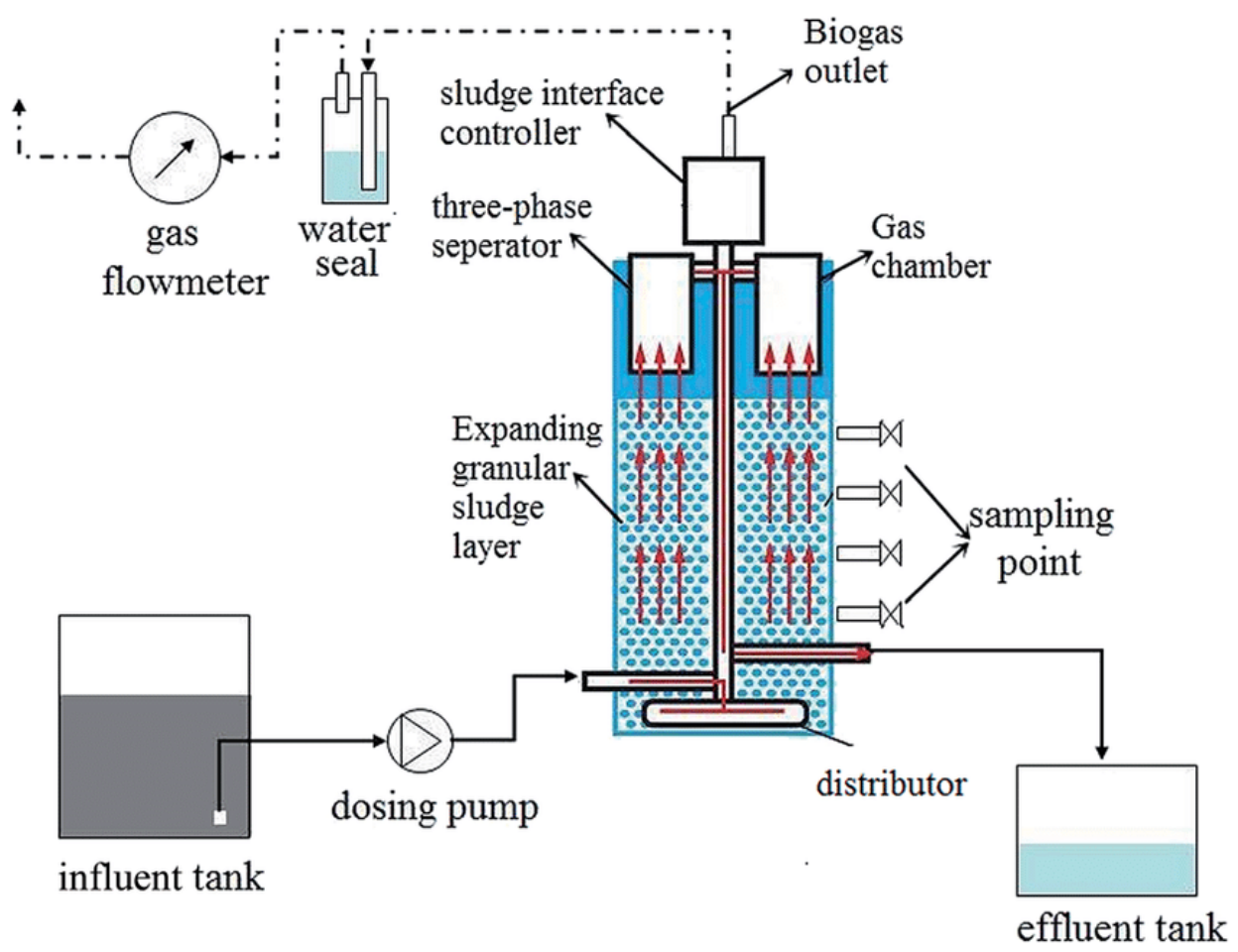

Fig. 14. Schematic diagram of an AnaEG [103].

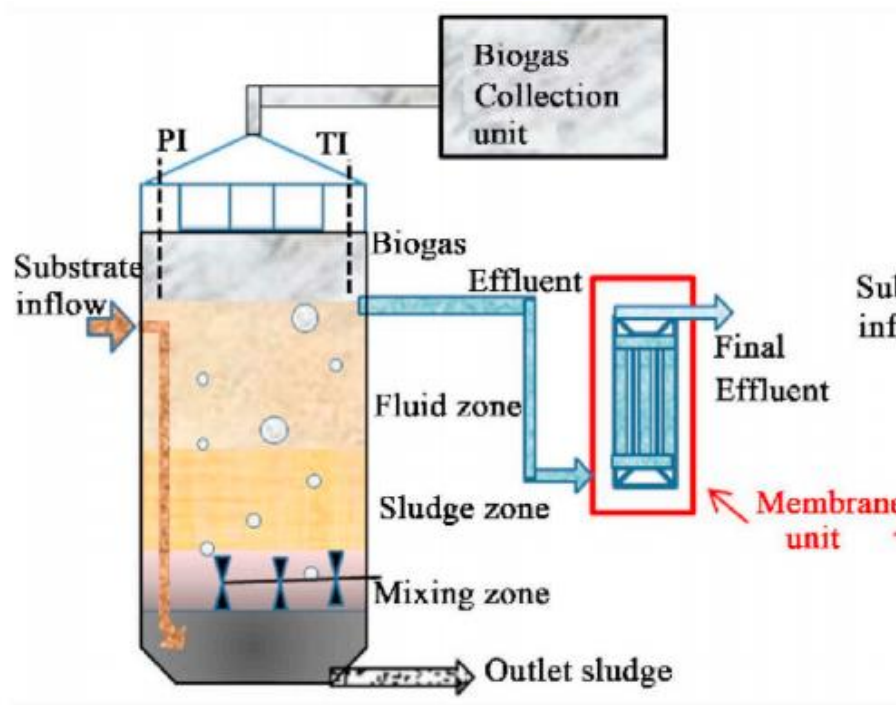

(a)

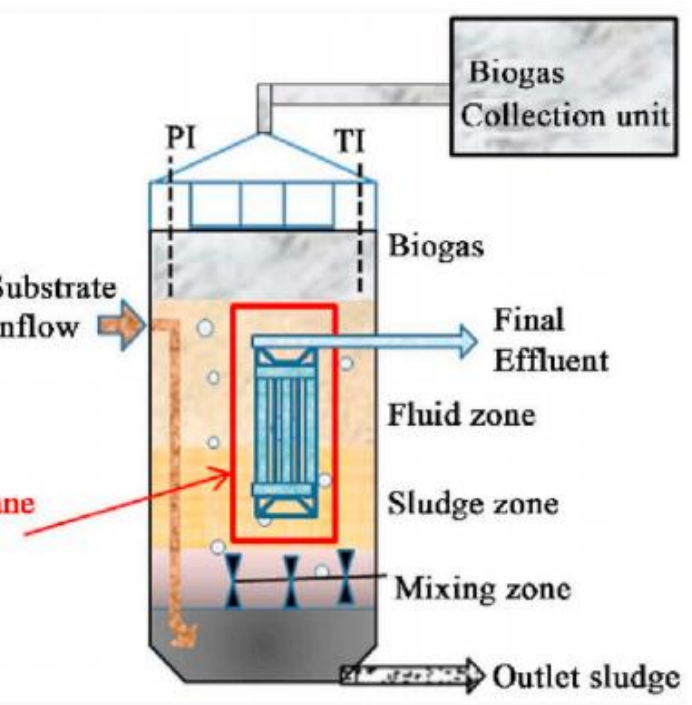

(b)

Fig. 15. Anaerobic membrane design: a) external cross flow, b) submerged [107].

4.3. Up-flow anaerobic sludge blanket-hollow centred packed bed Another novel high-rate anaerobic reactor used for the treatment of POME is the UASB-HCPB reactor, which closely resembles the UASFF. The primary difference is that the hollow cylindrical channel of the UASB-HCPB reactor is positioned vertically in the middle section of the packed bed. The hollow cylindrical channel in the packed bed is implemented to overcome the problem of clogging that occurs in a UASFF [119].

A UASB-HCPB reactor can be divided into three sections: UASB, HCPB, and the top section (Fig. 16). $P O M E$ is fed into the reactor from the bottom into the sludge bed, and the recirculation pump enhances contact between the substrate and the microbe in the UASB section. Suspended microbes are then attached to the pall rings in the HCPB section to form an attached growth system. Finally, 
the biogas produced in the UASB and HCPB sections rises to the top section, which contains a gasliquid-solid (GLS) separator, which acts as a medium for the production of biogas [120].

Several studies have been conducted on the use of mesophilic and thermophilic conditions in a UASB-HPCB reactor for the treatment of POME $[119,120]$. It has been evidenced that thermophilic conditions (55-65C) achieved a higher removal of COD and biogas production rate than mesophilic conditions (28C). A study of mesophilic conditions in UASB-HCPB reactor by Chan et al. [119] showed that as much as $86.7 \%$ COD can be removed with a biogas production rate of $0.448 \mathrm{~L} \mathrm{CH} 4 / \mathrm{L} /$ day. Meanwhile, thermophilic studies by Poh and Chong [120] reveal that $92.6 \%$ COD was removed from POME, with $67.5 \%$ methane content and $19.26 \mathrm{~L} \mathrm{CH} 4 / \mathrm{L} /$ day for biogas production. The advantages and disadvantages of all viable anaerobic reactors used to treat POME are summarised in Table 6.

Table 6

Available bioreactor to treat POME for high yield of biogas production.

\begin{tabular}{|c|c|c|c|}
\hline $\begin{array}{l}\text { Anaerobic } \\
\text { reactor }\end{array}$ & Advantages & Disadvantages & Reference \\
\hline $\begin{array}{l}\text { Single stage } \\
\text { reactor }\end{array}$ & $\begin{array}{l}\text { - Cost reduction } \\
\text { - Low maintenance } \\
\text { - Widely used due to its simplicity }\end{array}$ & $\begin{array}{l}\text { - Low OLR } \\
\text { - Took longer retention time } \\
\text { - Not economically feasible } \\
\text { - Higher chances for } \\
\text { explosion } \\
\text { - Low process stability in pH } \\
\text { control } \\
\text { - Accumulation of inhibitors } \\
\text { such as VFA and } \\
\text { toxic compounds. }\end{array}$ & {$[31,84]$} \\
\hline $\begin{array}{l}\text { Multi stage } \\
\text { digestion } \\
\text { reactor }\end{array}$ & $\begin{array}{l}\text { - Highly recommended for } \\
\text { treatment of organic } \\
\text { wastes with high lipid contents } \\
\text { especially POME } \\
\text { - Increase the stability of anaerobic } \\
\text { digestion process by separating } \\
\text { the acidogenic and methanogenic } \\
\text { stage. } \\
\text { - Provide process optimisation for } \\
\text { each microbe } \\
\text { group } \\
\text { - Increase VS/COD reduction } \\
\text { efficiencies } \\
\text { - Low retention time. }\end{array}$ & $\begin{array}{l}\text { - Hydrogen build-up inhibit } \\
\text { acidogenic bacteria } \\
\text { - Elimination of nutrient } \\
\text { required by } \\
\text { methanogenic bacteria } \\
\text { - Complex maintenance } \\
\text { - Higher startup and } \\
\text { operation cost } \\
\text { - Require skilled workers to } \\
\text { operate the system }\end{array}$ & {$[31,49,84]$} \\
\hline $\begin{array}{l}\text { Anaerobic } \\
\text { membrane } \\
\text { reactor } \\
\text { (AnMBR) }\end{array}$ & $\begin{array}{l}\text { - Low energy consumption } \\
\text { - Smaller space requirement } \\
\text { - Higher removal efficiency of } \\
\text { pollutants } \\
\text { - Adaptability to fluctuations in } \\
\text { organic loading } \\
\text { - Not affected by granulation } \\
\text { properties }\end{array}$ & $\begin{array}{l}\text { - Membrane prone to fouling } \\
\text { - Longer solid retention time } \\
\text { - Required strict cleaning } \\
\text { protocol } \\
\text { - Short lifetime of membrane } \\
\text { - Required high pressure }\end{array}$ & {$[101,105]$} \\
\hline $\begin{array}{l}\text { Anaerobic } \\
\text { fluidized } \\
\text { bedreactor } \\
\text { (AFBR) }\end{array}$ & $\begin{array}{l}\text { - Large surface area for biomass } \\
\text { transfer } \\
\text { - Less production of sludge } \\
\text { - Adaptability to shock-load }\end{array}$ & $\begin{array}{l}\text { - Inappropriate for high } \\
\text { suspended solids } \\
\text { - Unable to capture } \\
\text { produced biogas }\end{array}$ & {$[26,106]$} \\
\hline
\end{tabular}




\begin{tabular}{|c|c|c|c|}
\hline & - High OLR at short HRT. & $\begin{array}{l}\text { - High energy requirement } \\
\text { - Additional cost due to the } \\
\text { use of carrier media }\end{array}$ & \\
\hline $\begin{array}{c}\text { Advanced } \\
\text { anaerobic } \\
\text { expanded } \\
\text { granular } \\
\text { sludge bed } \\
\text { (AnaEG) }\end{array}$ & $\begin{array}{l}\text { - A state of the art reactor design } \\
\text { for POME } \\
\text { - Reduced power consumption as it } \\
\text { does not } \\
\text { requires recirculation pump to } \\
\text { adjust and maintain } \\
\text { the expansion } \\
\text { - Capable to pick up OLR up to } 50 \\
000 \mathrm{mg} \mathrm{L}^{-1} \text { COD } \\
\text { - Greater adaptability to shock-load } \\
\text { - Higher organic matter removal } \\
\text { rate above } 90 \% \text {. }\end{array}$ & $\begin{array}{l}\text { - Technical complexity } \\
\text { - Limited study on } \\
\text { composition and distribution } \\
\text { of } \\
\text { microbial community } \\
\text { structure that responsible } \\
\text { for the bioreactor's } \\
\text { treatment performance. }\end{array}$ & {$[94,95]$} \\
\hline $\begin{array}{l}\text { Anaerobic } \\
\text { sequencing } \\
\text { batch } \\
\text { reactor } \\
\text { (ASBR) }\end{array}$ & $\begin{array}{l}\text { - Cost effectiveness } \\
\text { - Flexible operation } \\
\text { - Retain high concentration of slow- } \\
\text { growing } \\
\text { anaerobic bacteria in the reactor } \\
\text { - Does not require separate clarifier }\end{array}$ & $\begin{array}{l}\text { - Poor self-immobilisation } \\
\text { - Low process performance } \\
\text { at high OLR } \\
\text { - Require supplementation of } \\
\text { nutrient to improve } \\
\text { POME treatment. }\end{array}$ & {$[18,24,26]$} \\
\hline $\begin{array}{l}\text { Continous } \\
\text { stirred tank } \\
\text { reactor } \\
\text { (CSTR) }\end{array}$ & $\begin{array}{l}\text { - Simple to operate } \\
\text { - Provides good contact between } \\
\text { wastewater and } \\
\text { microorganisms through mixing } \\
\text { - Lower operating cost and } \\
\text { maintenance } \\
\text { - Suitable for wastewaters with } \\
\text { high solid content } \\
\text { - Preferable for industrial scale of } \\
\text { POME treatment }\end{array}$ & $\begin{array}{l}\text { - Slow methanogenic } \\
\text { reactions rates at high OLRs } \\
\text { - Washout of active biomass } \\
\text { growing in } \\
\text { suspension at short HRT } \\
\text { - Intensive mixing lead to } \\
\text { process instabilities and } \\
\text { induced shear stress } \\
\text { - Corrosion of steel tanks }\end{array}$ & {$[22,93,107]$} \\
\hline $\begin{array}{l}\text { Expanded } \\
\text { granular } \\
\text { sludge bed } \\
\text { (EGSB) }\end{array}$ & $\begin{array}{l}\text { - Provide sufficient attachment } \\
\text { between biomass } \\
\text { and sludge } \\
\text { - Suitable for soluble pollutant } \\
\text { treatments especially } \\
\text { low-strength wastewater. } \\
\text { - Removal of suspended solids is } \\
\text { directly } \\
\text { proportional to the up flow } \\
\text { velocity }\end{array}$ & $\begin{array}{l}\text { - Requires a recirculation } \\
\text { pump and increase } \\
\text { power consumption. } \\
-\quad \text { Lower adaptability to } \\
\text { shock-load } \\
-\quad \text { Lower organic matter } \\
\text { removal rate below } 70- \\
75 \% \\
\text { - Formation of scum and } \\
\text { blockage of pipeline }\end{array}$ & {$[108,109]$} \\
\hline $\begin{array}{l}\text { Upflow } \\
\text { anaerobic } \\
\text { filtration } \\
\text { (UAF) }\end{array}$ & $\begin{array}{l}\text { - Retain denser microorganisms in } \\
\text { the reactor } \\
\text { - Able to capture biogas in the } \\
\text { reactor } \\
\text { - Short HRT }\end{array}$ & $\begin{array}{l}\text { - Clogging at high OLR due to } \\
\text { formation of } \\
\text { suspended solids in the } \\
\text { POME } \\
\text { - Addition of buffer is } \\
\text { required at high OLR to } \\
\text { prevent the excessive } \\
\text { accumulation of free acids }\end{array}$ & {$[110,111]$} \\
\hline $\begin{array}{l}\text { Upflow } \\
\text { anaerobic }\end{array}$ & $\begin{array}{l}\text { - Requires less reactor volume and } \\
\text { space }\end{array}$ & $\begin{array}{l}\text { - Highly depend on the } \\
\text { sludge settleability }\end{array}$ & {$[92,112,113]$} \\
\hline
\end{tabular}




\begin{tabular}{|c|c|c|c|}
\hline $\begin{array}{l}\text { sludge } \\
\text { blanket } \\
\text { (UASB) }\end{array}$ & $\begin{array}{l}\text { - Enables solid-liquid-gas } \\
\text { separation to occur in a } \\
\text { single reactor } \\
\text { - Provide sufficient attachment } \\
\text { between wastewater } \\
\text { and sludge even at low OLR } \\
\text { - Short HRT } \\
\text { - Higher operational stability }\end{array}$ & $\begin{array}{l}\text { - Took a longer startup } \\
\text { period } \\
\text { - Wash-out of active biomass } \\
\text { during the initial } \\
\text { phase of the process } \\
\text { - Foaming and sludge } \\
\text { flotation at high OLR }\end{array}$ & \\
\hline $\begin{array}{l}\text { Upflow } \\
\text { anaerobic } \\
\text { sludge } \\
\text { blanket- } \\
\text { hollow } \\
\text { centered } \\
\text { packed bed } \\
\text { (UASB-HCPB) }\end{array}$ & $\begin{array}{l}\text { - Reduce the cost required for the } \\
\text { packing materials } \\
\text { - Less maintenance due to less } \\
\text { clogging problems } \\
\text { - Adaptability to high load } \\
\text { - Provides greater biomass surface } \\
\text { area } \\
\text { - Shorter HRT }\end{array}$ & $\begin{array}{l}\text { - Technical complexity } \\
\text { - Requires a recirculation } \\
\text { pump and increase } \\
\text { power consumption } \\
\text { - Short HRT lead to sludge } \\
\text { washout due to high } \\
\text { upflow sheer force }\end{array}$ & {$[103,104]$} \\
\hline $\begin{array}{c}\text { Up-flow } \\
\text { anaerobic } \\
\text { sludge fixed- } \\
\text { film (UASFF) }\end{array}$ & $\begin{array}{l}\text { - Ablility to retain biomass in the } \\
\text { reactor for higher } \\
\text { organic loading } \\
\text { - High ratio of effluent recycle } \\
\text { - Greater stability than UASB when } \\
\text { operated under } \\
\text { high OLR } \\
\text { - Tolerate to temperature changes } \\
\text { in the range of } \\
24-50{ }^{\circ} \mathrm{C} \text { without remarkable } \\
\text { changes in the } \\
\text { process stability }\end{array}$ & $\begin{array}{l}\text { - Not suitable for industrial } \\
\text { level due to failure of } \\
\text { upscaling process } \\
\text { - Poor separation between } \\
\text { treated effluent and } \\
\text { biomass }\end{array}$ & {$[92,113,114]$} \\
\hline
\end{tabular}




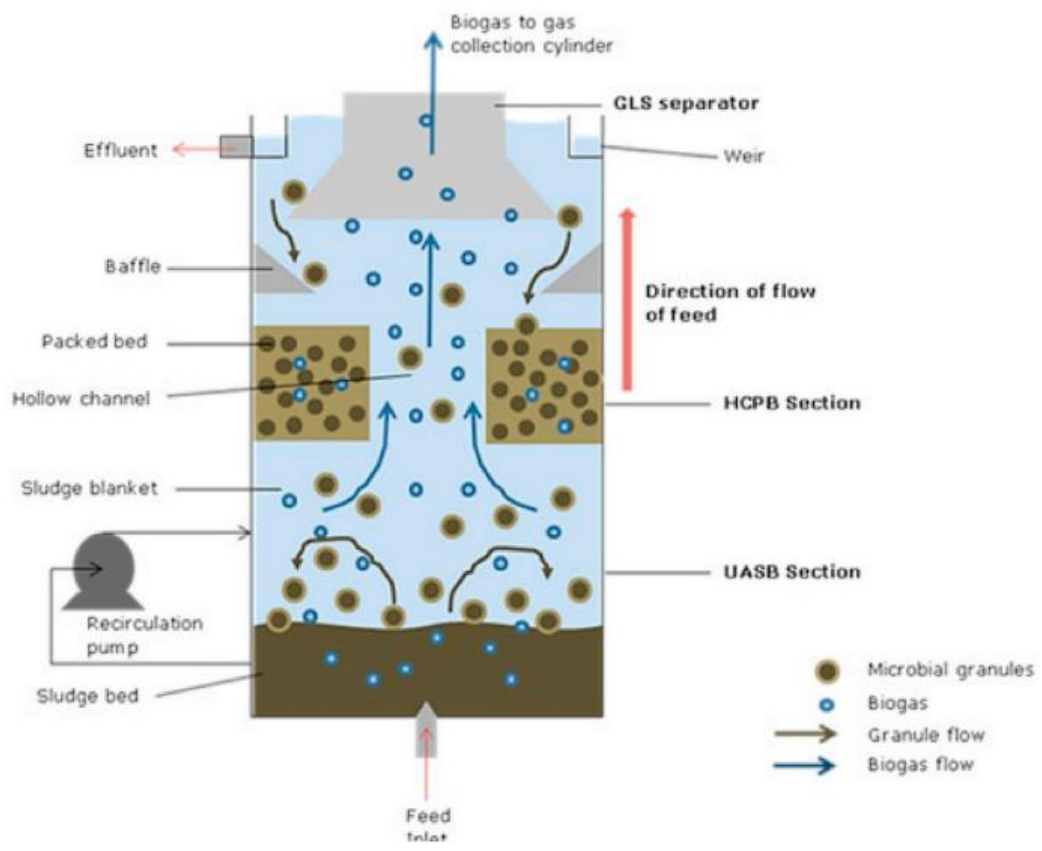

Fig. 16. Design of a UASB-HCPB reactor [120].

\section{Concluding remarks}

The use of biomass-to-energy techniques has provided prospects for future renewable energy applications. Currently, there is a focus on the use of biogas from various types of substrates, such as municipal solid waste, agricultural residue, animal manure, and household waste. The utilisation of biogas as a source of energy improves sanitation, reduces waste deposition, and minimises environmental pollution. A leading substrate for biogas production is POME, which can be found primarily in Southeast Asian countries. POME, being rich inorganic content, is a suitable raw material for anaerobic digestion. However, since POME is considered a lignocellulosic residue, recalcitrant substrates could remain in POME if it is not pretreated appropriately.

Over the past few decades, the pretreatment of POME has increased the biodegradability of the material, ultimately leading to high biogas yields. This paper summarises existing pretreatment methods suitable for POME and recommends recently manufactured high-rate anaerobic reactors that promote the maximum generation of biogas from POME. Acidified POME utilisation, ash addition, co-digestion, coagulationflocculation, de-oiling, dissolved air flotation, enzymatic hydrolysis, microwave irradiation, immobilisation media, ozonation, and ultrasonication are suitable pretreatment techniques for POME that can increase the production of biogas. Acidified POME utilisation and ash addition have yielded 260.3 and $218.79 \mathrm{~L} \mathrm{CH} 4 / \mathrm{kgCOD}$, respectively. A maximum yield of $480 \mathrm{~L} \mathrm{CH} 4 / \mathrm{kgCOD}$ was observed when POME was codigested with microalgae, and $340 \mathrm{~L}$ $\mathrm{CH} 4 / \mathrm{kgCOD}$ was recorded through the coagulation/flocculation of POME with chitosan. De-oiled POME, enzymatic hydrolysis, and microwave irradiation pretreatments produced maximum yields of $600 \mathrm{~L} \mathrm{CH} 4 / \mathrm{kgVS}, 914 \mathrm{~L} \mathrm{CH} 4 / \mathrm{kgVS}$, and $58 \mathrm{~L} \mathrm{CH} 4 / \mathrm{kgCOD}$, respectively. In addition, cement kiln dust immobilisation media, ozonation, and ultrasonic pretreatments produced maximum yields of $650 \mathrm{~L}$ $\mathrm{CH} 4 / \mathrm{kgCOD}, 410 \mathrm{~L} \mathrm{CH} 4 / \mathrm{kgCOD}$, and $44 \mathrm{~L} \mathrm{CH} 4 / \mathrm{kgCOD}$, respectively. The design and configuration of new high-rate anaerobic reactors - namely, granular sludge beds, anaerobic membranes, and upflow anaerobic sludge blanket-hollow centred packed beds - are presented in this article. These reactors provide optimum efficiency in the digestion process and result in a significant increase in methane yields from POME. To date, combined pretreatments for POME have been required to maximise the potential removal of pollutants and increase biogas production efficiency. However, techno-economic analyses must be considered for the pretreatment techniques used for POME. Moreover, cost analyses of reactor operations must be conducted to extend the research and 
development from laboratory studies to pilot-scale studies. Laboratory-scale research shows the significant potential of biogas production after the treatment of POME, suggesting that laboratoryscale studies should be upscaled to industrial-scale biogas production. Surely, this would provide a platform for the sustainable and environmentally friendly production of energy resources for future generations.

\section{Acknowledgements}

The authors would like to thank the Ministry of Higher Education and Universiti Teknologi Malaysia (UTM) for their research grant (Vote No. 19H98). Otherwise, this research would not have been possible. The authors shall remain indebted to all of them for their kindness and generosity.

\section{References}

[1] Lim JS, Abdul Manan Z, Wan Alwi SR, Hashim H. A review on utilisation of biomass from rice industry as a source of renewable energy. Renew Sustain Energy Rev 2012;16:3084-94.

https://doi.org/10.1016/i.rser.2012.02.051.

[2] BP Energy Economics. BP energy outlook 2018 BP Energy outlook. 2018 BP energy outlook. 2018. https://doi.org/10.1088/1757-899X/342/1/012091. 2018.

[3] Lonnqvist $€ T$, Sanches-Pereira A, Sandberg T. Biogas potential for sustainable transport - a Swedish regional case. J Clean Prod 2015;30:1-10. https://doi.org/ 10.1016/j.jclepro.2015.07.036.

[4] Babel S, Sae-Tang J, Pecharaply A. Anaerobic co-digestion of sewage and brewery sludge for biogas production and land application. Int J Environ Sci Technol 2009;6:131-40.

https://doi.org/10.1007/BF03326067.

[5] Scarlat N, Fahl F, Dallemand JF, Monforti F, Motola V. A spatial analysis of biogas potential from manure in Europe. Renew Sustain Energy Rev 2018;94:915-30.

https://doi.org/10.1016/j.rser.2018.06.035.

[6] Paolini V, Petracchini F, Carnevale M, Gallucci F, Perilli M, Esposito G, et al. Characterisation and cleaning of biogas from sewage sludge for biomethane production. J Environ Manag 2018;217:28896. https://doi.org/10.1016/j. jenvman.2018.03.113.

[7] Latha K, Velraj R, Shanmugam P, Sivanesan S. Mixing strategies of high solids anaerobic Codigestion using food waste with sewage sludge for enhanced biogas production. J Clean Prod 2018;210:388-400.

[8] O-Thong S, Boe K, Angelidaki I. Thermophilic anaerobic co-digestion of oil palm empty fruit bunches with palm oil mill effluent for efficient biogas production. Appl Energy 2012;93:648-54. https://doi.org/10.1016/i.apenergy.2011.12.092.

[9] Zhang R, El-Mashad HM, Hartman K, Wang F, Liu G, Choate C, et al. Characterization of food waste as feedstock for anaerobic digestion. Bioresour Technol 2007;98:929-35.

https://doi.org/10.1016/i.biortech.2006.02.039.

[10] Sidik Umar Hayatu, Razali Firdausi bin, Sharifah Rafidah Wan Alwi FM, Sidik UH, Razali F, Alwi SRW, Maigari F. Biogas production through Co-digestion of palm oil mill effluent with cow manure. Nigerian Journal of Basic and Applied Science 2013;21:79-84.

https://doi.org/10.4314/njbas.v21i1.12.

[11] Poschl $€ \mathrm{M}$, Ward S, Owende P. Evaluation of energy efficiency of various biogas production and utilization pathways. Appl Energy 2010;87:3305-21. https://doi.

org/10.1016/j.apenergy.2010.05.011.

[12] Chae KJ, Jang A, Yim SK, Kim IS. The effects of digestion temperature and temperature shock on the biogas yields from the mesophilic anaerobic digestion of swine manure. Bioresour Technol 2008;99:1-6. https://doi.org/10.1016/j. biortech.2006.11.063.

[13] Velmurugan B, Ramanujam RA. Anaerobic digestion of vegetable wastes for biogas production in a fed-batch reactor. Int J Emerg Sci 2011;1:478-86. 
[14] Iskandar MJ, Baharum A, Anuar FH, Othaman R. Palm oil industry in South East Asia and the effluent treatment technology-a review. Environ Technol Innovat 2018;9:169-85.

https://doi.org/10.1016/j.eti.2017.11.003.

[15] Zhang Y, Yan L, Chi L, Long X, Mei Z, Zhang Z. Startup and operation of anaerobic EGSB reactor treating palm oil mill effluent. J Environ Sci 2008;20:658-63. https://doi.org/10.1016/S10010742(08)62109-9.

[16] Saifuddin N, Fazlili SA. Effect of microwave and ultrasonic pretreatments on biogas production from anaerobic digestion of palm oil mill effluent. Am J Eng Appl Sci 2009;2:139-46.

[17] Poh PE, Chong MF. Biomethanation of Palm Oil Mill Effluent (POME) with a thermophilic mixed culture cultivated using POME as a substrate. Chem Eng J 2010;164:146-54.

https://doi.org/10.1016/j.cej.2010.08.044.

[18] Chaiprapat S, Laklam T. Enhancing digestion efficiency of POME in anaerobic sequencing batch reactor with ozonation pretreatment and cycle time reduction. Bioresour Technol 2011;102:4061-8. https://doi.org/10.1016/j. biortech.2010.12.033.

[19] Kim SH, Choi SM, Ju HJ, Jung JY. Mesophilic co-digestion of palm oil mill effluent and empty fruit bunches. Environ Technol 2013;34:2163-70. https://doi. org/10.1080/09593330.2013.826253.

[20] Tanikkula P, Chantoom K, Phoochinda W, Pisutpaisal N. Improvement of biomethane production yield from palm oil mill effluent using ozonation process. Energy Procedia 2014:2239-43.

https://doi.org/10.1016/j.egypro.2014.12.117.

[21] Tabassum S, Zhang Y, Zhang Z. An integrated method for palm oil mill effluent (POME) treatment for achieving zero liquid discharge - a pilot study. J Clean Prod 2015;95:148-55.

https://doi.org/10.1016/j.jclepro.2015.02.056.

[22] Khemkhao M, Techkarnjanaruk S, Phalakornkule C. Effect of chitosan on reactor performance and population of specific methanogens in a modified CSTR treating raw POME. Biomass Bioenergy 2016;86:11-20. https://doi.org/10.1016/j. biombioe.2016.01.002.

[23] Prasertsan P, Khangkhachit W, Duangsuwan W, Mamimin C, O-Thong S. Direct hydrolysis of palm oil mill effluent by xylanase enzyme to enhance biogas production using two-steps thermophilic fermentation under non-sterile condition. Int J Hydrogen Energy 2017;42:27759-66. https://doi.org/10.1016/j. ijhydene.2017.05.140.

[24] Abd Nasir MA, Jahim JM, Abdul PM, Silvamany H, Maaroff RM, Mohammed Yunus MF. The use of acidified palm oil mill effluent for thermophilic biomethane production by changing the hydraulic retention time in anaerobic sequencing batch reactor. Int J Hydrogen Energy 2018.

https://doi.org/10.1016/j. ijhydene.2018.06.149.

[25] Tan YD, Lim JS. Feasibility of palm oil mill effluent elimination towards sustainable Malaysian palm oil industry. Renew Sustain Energy Rev 2019;111: 507-22.

https://doi.org/10.1016/i.rser.2019.05.043.

[26] Ahmad A, Ghufran R, Wahid ZA. Bioenergy from anaerobic degradation of lipids in palm oil mill effluent. Rev Environ Sci Biotechnol 2011;10:353-76. https:// doi.org/10.1007/s11157-011-9253-8. [27] Ahmed Y, Yaakob Z, Akhtar P, Sopian K. Production of biogas and performance evaluation of existing treatment processes in palm oil mill effluent (POME). Renew Sustain Energy Rev 2015;42:1260-78. https://doi.org/10.1016/j. rser.2014.10.073.

[28] Hosseini SE, Bagheri G, Wahid MA, Saat A. Clean fuel, clean energy conversion technology: experimental and numerical investigation of palm oil mill effluent biogas flameless combustion. BioResources 2015;10:6597-609.

[29] Sridhar MKC, Adeoluwa OO. Palm oil industry residues. Biotechnology for agroindustrial residues utilisation: Utilisation of Agro-Residues. 2009. https://doi. org/10.1007/978-1-4020-99427 78.

[30] Gozan M, Aulawy N, Rahman SF, Budiarto R. Techno-economic analysis of biogas power plant from POME (palm oil mill effluent). Int J Appl Eng Res 2018;13: 6151-7. 
[31] Ohimain El, Izah SC. A review of biogas production from palm oil mill effluents using different configurations of bioreactors. Renew Sustain Energy Rev 2017;70: 242-53.

https://doi.org/10.1016/j.rser.2016.11.221.

[32] Divya D, Gopinath LR, Merlin Christy P. A review on current aspects and diverse prospects for enhancing biogas production in sustainable means. Renew Sustain Energy Rev 2015;42:690-9. https://doi.org/10.1016/i.rser.2014.10.055.

[33] Bajpai P. Basics of anaerobic digestion process. Anaerobic technology in pulp and paper industry. 2017. p. 7-12. https://doi.org/10.1007/978-981-10-4130-3 2.

[34] Lam MK, Lee KT. Renewable and sustainable bioenergies production from palm oil mill effluent (POME): win-win strategies toward better environmental protection. Biotechnol Adv 2011;29:12441.

[35] Sasaki D, Hori T, Haruta S, Ueno Y, Ishii M, Igarashi Y. Methanogenic pathway and community structure in a thermophilic anaerobic digestion process of organic solid waste. J Biosci Bioeng 2011;111:41-6. https://doi.org/10.1016/j. jbiosc.2010.08.011.

[36] Kumaran P, Hephzibah D, Sivasankari R, Saifuddin N, Shamsuddin AH. A review on industrial scale anaerobic digestion systems deployment in Malaysia: opportunities and challenges. Renew Sustain Energy Rev 2016;56:929-40. https://doi.org/10.1016/i.rser.2015.11.069.

[37] Wang B. Factors that influence the biochemical Methane potential (BMP) test steps towards the standardisation of BMP test. 2016.

[38] Fountoulakis MS, Petousi I, Manios T. Co-digestion of sewage sludge with glycerol to boost biogas production. Waste Manag 2010;30:1849-53. https://doi.org/

10.1016/j.wasman.2010.04.011.

[39] Sitorus B, Sukandar D, Panjaitan S. Biogas recovery from anaerobic digestion process of mixed fruit -vegetable wastes. Energy Procedia 2013;32:176-82.

[40] Chen S, Zhang J, Wang X. Effects of alkalinity sources on the stability of anaerobic digestion from food waste. Waste Manag Res 2015;33:1033-40. https://doi.org/ 10.1177/0734242X15602965.

[41] Reungsang A, Pattra S, Sittijunda S. Optimization of key factors affecting methane production from acidic effluent coming from the sugarcane juice hydrogen fermentation process. Energies 2012;5:4746-57. https://doi.org/10.3390/ en5114746.

[42] Labatut Ra, Gooch Ca. Monitoring of anaerobic digestion process to optimize performance and prevent system failure. In: Proceedings of got manure? Enhancing environmental and economic sustainability; 2012. p. 209-25.

[43] Achinas S, Achinas V, Euverink GJW. A technological overview of biogas production from biowaste. Engineering 2017;3:299-307. https://doi.org/ 10.1016/J.ENG.2017.03.002.

[44] Lay C-H, Kumar G, Mudhoo A, Lin C-Y, Leu H-J, Shobana S, et al. Recent trends and prospects in biohythane research: an overview. Int J Hydrogen Energy 2019.

https://doi.org/10.1016/j.ijhydene.2019.07.209.

[45] Krishnan S, Singh L, Sakinah M, Thakur S, Wahid ZA, Alkasrawi M. Process enhancement of hydrogen and methane production from palm oil mill effluent using two-stage thermophilic and mesophilic fermentation. Int J Hydrogen Energy 2016;41:12888-98.

[46] O-Thong S, Suksong W, Promnuan K, Thipmunee M, Mamimin C, Prasertsan P. Two-stage thermophilic fermentation and mesophilic methanogenic process for biohythane production from palm oil mill effluent with methanogenic effluent recirculation for $\mathrm{pH}$ control. Int J Hydrogen Energy 2016;41:21702-12. https:// doi.org/10.1016/j.ijhydene.2016.07.095.

[47] Krishnan S, Singh L, Sakinah M, Thakur S, Nasrul M, Otieno A, et al. An investigation of two-stage thermophilic and mesophilic fermentation process for the production of hydrogen and methane from palm oil mill effluent. Environ Prog Sustain Energy 2017;36:895-902.

https://doi.org/10.1002/ep.12537.

[48] Seengenyoung J, Mamimin C, Prasertsan P, O-Thong S. Pilot-scale of biohythane production from palm oil mill effluent by two-stage thermophilic anaerobic fermentation. Int J Hydrogen Energy 2018. https://doi.org/10.1016/j. ijhydene.2018.08.021. 
[49] Mamimin C, Singkhala A, Kongjan P. Two-stage thermophilic fermentation and mesophilic methanogen process for biohythane production from palm oil mill effluent. Int J Hydrogen Energy 2015;40:6319-28. https://doi.org/10.1016/j. ijhydene.2015.03.068.

[50] Mamimin C, Probst M, Gomez-Brandmon M, Podmirseg SM, Insam H, Reungsang A, et al. Trace metals supplementation enhanced microbiota and biohythane production by two-stage thermophilic fermentation. Int J Hydrogen Energy 2019. https://doi.org/10.1016/j.ijhydene.2018.09.065. [51] Tan L, Qu Y, Zhou J, Ma F, Li A. Dynamics of microbial community for X-3B wastewater decolorization coping with high-salt and metal ions conditions. Bioresour Technol 2009;100:3003-9. https://doi.org/10.1016/j. biortech.2009.01.010.

[52] Lo HM, Liu MH, Pai TY, Liu WF, Lin CY, Wang SC, et al. Biostabilization assessment of MSW codisposed with MSWI fly ash in anaerobic bioreactors. J Hazard Mater 2009;162:1233-42. https://doi.org/10.1016/j. jhazmat.2008.06.028.

[53] Kutty SRM, Ngatenah SNI, Johan NA, Amat KAC. Removal of Zn ( II ), Cu ( II ), chemical oxygen demand ( COD) and colour from anaerobically treated palm oil mill effluent ( POME ) using microwave incinerated rice husk ash ( MIRHA ). Int Conf Environ Ind Innovat 2011;12:90-4. [54] Jijai S, Muleng S, Siripatana C. Effect of dilution and ash supplement on the biomethane potential of palm oil mill effluent (POME). AIP Conference Proceedings 2017;1868:020013. [55] Mamimin C, Thongdumyu P, Hniman A, Prasertsan P, Imai T, O-Thong S. Simultaneous thermophilic hydrogen production and phenol removal from palm oil mill effluent by Thermoanaerobacterium-rich sludge. Int J Hydrogen Energy 2012;37. https://doi.org/10.1016/j.ijhydene.2012.04.062.1559 8-15606.

[56] Hagos K, Zong J, Li D, Liu C, Lu X. Anaerobic co-digestion process for biogas production: progress, challenges and perspectives. Renew Sustain Energy Rev 2017;76:1485-96.

https://doi.org/10.1016/j.rser.2016.11.184.

[57] Mata-Alvarez J, Dosta J, Romero-Güiza MS, Fonoll X, Peces M, Astals S. A critical review on anaerobic co-digestion achievements between 2010 and 2013. Renew Sustain Energy Rev 2014;36:412-27. https://doi.org/10.1016/j. rser.2014.04.039.

[58] Neshat SA, Mohammadi M, Najafpour GD, Lahijani P. Anaerobic co-digestion of animal manures and lignocellulosic residues as a potent approach for sustainable biogas production. Renew Sustain Energy Rev 2017;79:308-22. https://doi.org/ 10.1016/j.rser.2017.05.137.

[59] Fajar, Faizal M, Novia. Effects of mesophilic and thermophilic temperature condition to biogas production (methane) from palm oil mill effluent (POME) with cow manures. Sci Technol Indones 2018;3:19-25.

[60] Nurliyana MY, H'ng PS, Rasmina H, Kalsom MSU, Chin KL, Lee SH, et al. Effect of C/N ratio in methane productivity and biodegradability during facultative codigestion of palm oil mill effluent and empty fruit bunch. Ind Crops Prod 2015;76: 409-15.

https://doi.org/10.1016/j.indcrop.2015.04.047.

[61] Alrawi RA, Ahmad A, Ismail N, Kadir MOA. Anaerobic co-digestion of palm oil mill effluent with rumen fluid as a co-substrate. Desalination 2011;269:50-7.

https://doi.org/10.1016/i.desal.2010.10.041.

[62] Suksong W, Kongjan P, O-Thong S. Biohythane production from Co-digestion of palm oil mill effluent with solid residues by two-stage solid state anaerobic digestion process. Energy Procedia 2015. https://doi.org/10.1016/j. egypro.2015.11.591.

[63] Sulaiman A, Sulaiman A, Zakaria MR, Hassan MA, Shirai Y, Busu Z. Co-digestion of palm oil mill effluent and refined glycerin wash water for chemical oxygen demand removal and methane production. Am J Environ Sci 2009;5:639-46. https://doi.org/10.3844/ajessp.2009.639.646.

[64] Khemkhao M, Nuntakumjorn B, Techkarnjanaruk S, Phalakornkule C. Effect of chitosan on UASB treating POME during a transition from mesophilic to thermophilic conditions. Bioresour Technol 2011;102:4674-81. https://doi.org/ 10.1016/j.biortech.2011.01.032. 
[65] Bala JD, Lalung J, Ismail N. Palm oil mill effluent (POME) treatment "Microbial Communities in an Anaerobic Digester": a review. Int J Sci Res Pub 2014;4. https://doi.org/10.1007/s10461-0119882-5.

[66] Saththasivam J, Loganathan K, Sarp S. An overview of oil-water separation using gas flotation systems. Chemosphere 2016;144:671-80. https://doi.org/10.1016/ j.chemosphere.2015.08.087. [67] Dewi R, Sari R, Syafruddin. The effect of the natural bentonite to reduce COD in palm oil mill effluent by using a hybrid adsorption-flotation method. IOP Conf Ser Mater Sci Eng 2017;210:012016.

[68] Poh PE, Ong WYJ, Lau EV, Chong MN. Investigation on micro-bubble flotation and coagulation for the treatment of anaerobically treated palm oil mill effluent (POME). J Environ Chem Eng 2014;2:1174-81. https://doi.org/10.1016/j. jece.2014.04.018.

[69] Fang C, O-Thong S, Boe K, Angelidaki I. Comparison of UASB and EGSB reactors performance, for treatment of raw and deoiled palm oil mill effluent (POME). J Hazard Mater 2011;189:229-34. https://doi.org/10.1016/j. jhazmat.2011.02.025.

[70] McCabe BK, Hamawand I, Harris P, Baillie C, Yusaf T. A case study for biogas generation from covered anaerobic ponds treating abattoir wastewater: investigation of pond performance and potential biogas production. Appl Energy 2014;114:798-808.

https://doi.org/10.1016/j.apenergy.2013.10.020.

[71] Budych-Gorzna M, Smoczynski M, Oleskowicz-Popiel P. Enhancement of biogas production at the municipal wastewater treatment plant by co-digestion with poultry industry waste. Appl Energy 2016;161:387-94. https://doi.org/10.1016/ j.apenergy.2015.10.007.

[72] Yang S, Phan H, Bustamante H, Guo W, Ngo H, Nghiem L. Effects of shearing on biogas production and microbial community structure during anaerobic digestion with recuperative thickening. Bioresour Technol 2017;234:439-47. https://doi. org/10.1016/j.biortech.2017.03.051. [73] Baharuddin AS, Hock LS, Yusof MZ, Abdul NA, Shah U, Hassan MA, et al. The effect of palm oil mill effluent (POME) anaerobic sludge from $500 \mathrm{~m} 3$ of closed anaerobic methane digested tank on pressed-shredded empty fruit bunch (EFB) composting process. Afr J Biotechnol 2010;9:2427-36. https://doi.org/10.5897/ AJB10.1418.

[74] Islam MT, Alam MZ, Al-Mamun A, Elgharbawy AA, Riyadi FA. Development of enzymatic pretreatment of palm oil mill effluent for monomers towards biogas production. J Adv Res Mater Sci 2017;38:39-44.

[75] Nomanbhay S, Hussain R. Microwave assisted alkaline pretreatment and microwave assisted enzymatic hydrolysis of palm oil mill effluent (POME) for optimum fermentable sugar yield. Chem Sci Trans 2014;3:350-8. https://doi. org/10.7598/cst2014.669.

[76] Mun WK, Rahman NAA, Abd-aziz S, Sabaratnam V, Hassan MA. Enzymatic hydrolysis of palm oil mill effluent solid using mixed cellulases from locally isolated fungi. Res J Microbiol 2008;3:474-81. https://doi.org/10.3923/jm.2008.474.481.

[77] Liew YX, Chan YJ, Show PL, Sivakumar M, Chong MF. Enzymatic pre-treatment of palm oil mill effluent (POME) for enhanced anaerobic digestion. In: Asia pacific confederation of chemical engineering congress; 2015. p. 1321.

[78] Kumar AK, Sharma S. Recent updates on different methods of pretreatment of lignocellulosic feedstocks: a review. Bioresour Bioprocess 2017;4:7. https://doi. org/10.1186/s40643-017-0137-9. [79] Suzana C udia SM, Claudia MAM, Larissa Guedes Fiuacute za MC o, Ra T dde S. Immobilization of microbial cells: a promising tool for treatment of toxic pollutants in industrial wastewater. Afr J Biotechnol 2013;12:4412-8. https:// doi.org/10.5897/AJB12.2677.

[80] Ayu ED, Halim L, Mellyanawaty M, Sudibyo H, Budhijanto W. The effect of natural zeolite as microbial immobilization media in anaerobic digestion at various concentrations of palm oil mill effluent (POME). AIP Conference Proceedings 2017. https://doi.org/10.1063/1.4982335.

[81] Wirawan SK, Sudibyo H, Setiaji MF, Warmada IW, Wahyuni ET. Development of natural zeolites adsorbent: chemical analysis and preliminary TPD adsorption study. J Eng Sci Technol 2015:87-95. 
[82] Ahmad A, Wahid ZA. Immobilized cement kiln dust enhances biomass and neutralizing of palm oil mill effluent for biogas production. Environ Prog Sustain Energy 2015;34:736-43.

https://doi.org/10.1002/ep.12057.

[83] Ramadhani LI, Damayanti SI, Sudibyo H, Budhijanto W. Kinetics of anaerobic digestion of palm oil mill effluent (POME) in double-stage batch bioreactor with recirculation and fluidization of microbial immobilization media. IOP Conf Ser Mater Sci Eng 2018. https://doi.org/10.1088/1757899X/316/1/012071.

[84] Halim L, Mellyanawaty M, Cahyono RB, Sudibyo H, Budhijanto W. Anaerobic digestion of palm oil mill effluent with lampung natural zeolite as microbe immobilization medium and digested cow manure as starter. AIP Conference Proceedings 2017. https://doi.org/10.1063/1.4982333. [85] Ahmad A. Application of cement kiln dust enhancing methane production using upflow anaerobic sludge blanket reactor for the treatment of palm oil mill effluent. Indian J Chem Technol 2016;23:31-8. https://doi.org/10.1080/09593330.2014.919034.

[86] Ahmad A. Effect of ozonation on biodegradation and methanogenesis of palm oil mill effluent treatment for the production of biogas. Ozone: Sci Eng 2019. https:// doi.org/10.1080/01919512.2019.1565987.

[87] Travaini R, Martín-Juarez J, Lorenzo-Hernando A, Bolado-Rodríguez S. Ozonolysis: an advantageous pretreatment for lignocellulosic biomass revisited. Bioresour Technol 2016;199:2-12. https://doi.org/10.1016/j. biortech.2015.08.143.

[88] Elliott A, Mahmood T. Pretreatment technologies for advancing anaerobic digestion of pulp and paper biotreatment residues. Water Res 2007;41:4273-86.

https://doi.org/10.1016/j.watres.2007.06.017.

[89] Aquino S, Pires EC. Assessment of ozone as a pretreatment to improve anaerobic digestion of vinasse. Braz J Chem Eng 2016;33:279-85. https://doi.org/10.1590/ 0104-

6632.20160332s20140141.

[90] Kavitha S, Rajesh Banu J, Subitha G, Ushani U, Yeom IT. Impact of thermochemo-sonic pretreatment in solubilizing waste activated sludge for biogas production: energetic analysis and economic assessment. Bioresour Technol 2016;219:479-86.

https://doi.org/10.1016/j.biortech.2016.07.115.

[91] Ushani U, Rajesh Banu J, Tamilarasan K, Kavitha S, Tae Yeom I. Surfactant coupled sonic pretreatment of waste activated sludge for energetically positive biogas generation. Bioresour Technol 2017;241:710-9. https://doi.org/10.1016/ j.biortech.2017.05.201.

[92] Lizama AC, Figueiras CC, Herrera RR, Pedreguera AZ, Ruiz Espinoza JE. Effects of ultrasonic pretreatment on the solubilization and kinetic study of biogas production from anaerobic digestion of waste activated sludge. Int Biodeterior Biodegrad 2017;123:1-9.

https://doi.org/10.1016/i.ibiod.2017.05.020.

[93] Deepanraj B, Sivasubramanian V, Jayaraj S. Biogas generation through anaerobic digestion process-an overview. Res J Chem Environ 2014;18. https://doi.org/ 10.1002/jnr.10365.

[94] Haan WW. Evaluation of ultrasonic pretreatment on anaerobic digestion of biomass for methane production. IOWA State University; 2008.

[95] Huzir NM, Aziz MMA, Ismail SBB, Abdullah B, Mahmood NAN, Umor NAA, et al. Agro-industrial waste to biobutanol production: eco-friendly biofuels for next generation. Renew Sustain Energy Rev 2018;94:476-85. https://doi.org/ 10.1016/j.rser.2018.06.036.

[96] Ahmad A, Shah SMU, Othman MF, Abdullah MA. Biomethane production and palm oil mill effluent treatment by co-cultivation of Nannochloropsis oculata. Appl Mech Mater 2014;625:81821. https://10.4028/www.scientific.net/AMM .625.818.

[97] Chow WL, Chan YJ, Chong MF, Poh PE. Co-digestion studies of saleable glycerin with palm oil mill effluent and poultry manure. J Eng Sci Technol 2015:17-26.

[98] Suksong W, Promnuan K, Seengenyoung J, O-Thong S. Anaerobic Co-digestion of palm oil mill waste residues with sewage sludge for biogas production. In: Energy procedia; 2017.

https://doi.org/10.1016/j.egypro.2017.10.068. 
[99] Kongjan P, Sama K, Sani K, Jariyaboon R, Reungsang A. Feasibility of bio-hythane production by co-digesting skim latex serum (SLS) with palm oil mill effluent (POME) through two-phase anaerobic process. Int J Hydrogen Energy 2018;43: 9577-90. https://doi.org/10.1016/j.ijhydene.2018.04.052. [100] Khemkhao M, Nuntakumjorn B, Techkarnjanaruk S, Phalakornkule C. Comparative mesophilic and thermophilic anaerobic digestion of palm oil mill effluent using upflow anaerobic sludge blanket. Water Environ Res 2012;84: 577-87. https://doi.org/10.2175/106143012X13378023685637. [101] Zinatizadeh AAL, Mohamed AR, Mashitah MD, Abdullah AZ, Isa MH. Optimization of pretreated palm oil mill effluent digestion in an up-flow anaerobic sludge fixed film bioreactor: a comparative study. Biochem Eng J 2007; 35:226-37. https://doi.org/10.1016/i.bej.2007.01.018. [102] Poh PE, Chong MF. Development of anaerobic digestion methods for palm oil mill effluent (POME) treatment. Bioresour Technol 2009;100:1-9. https://doi.org/ 10.1016/j.biortech.2008.06.022.

[103] Li C, Tabassum S, Zhang Z. An advanced anaerobic expanded granular sludge bed (AnaEG) for the treatment of coal gasification wastewater. RSC Adv 2014;4: 57580-6.

https://doi.org/10.1039/c4ra08042d.

[104] Qin X, Wu X, Li L, Li C, Zhang Z, Zhang X. The advanced anaerobic expanded granular sludge bed (AnaEG) possessed temporally and spatially stable treatment performance and microbial community in treating starch processing wastewater. Front Microbiol 2018;9:589.

https://doi.org/10.3389/fmicb.2018.00589.

[105] Kheang LS, Lai ME, Ngatiman M, Soon LW, May CY. An integrated anaerobicaerobic treatment of palm oil mill effluent to achieve zero discharge. Palm Oil Eng Bulletin 2015.

[106] Loh SK, Lai ME, Ngatiman M, Lim WS, Choo YM, Zhang Z, et al. Zero discharge treatment technology of palm oil mill effluent. J. Oil Palm Res. 2013;25:273-81.

[107] Jain M. Anaerobic membrane bioreactor as highly efficient and reliable technology for wastewater treatment-a review. Adv Chem Eng Sci 2018;8: 720-6.

https://doi.org/10.4236/aces.2018.82006.

[108] Ylitervo P, Akinbomi J, Taherzadeh MJ. Membrane bioreactors potential for ethanol and biogas production: a review. Environ Technol 2013;34:1711-23.

https://doi.org/10.1080/09593330.2013.813559.

[109] Judd S. The MBR book: principles and applications of Membrane bioreactors for water and wastewater. 2011. https://doi.org/10.1016/B978-0-08-096682- 3.10007-1.

[110] Abdulsalam M, Man HC, Idris Al, Yunos KF, Abidin ZZ. Treatment of palm oil mill effluent using membrane bioreactor: novel processes and their major drawbacks. Water 2018;10:1165.

https://doi.org/10.3390/w10091165.

[111] Abdurahman NH, Rosli YM, Azhari NH. Development of a membrane anaerobic system (MAS)

for palm oil mill effluent (POME) treatment. Desalination 2011; 266:208-12.

https://doi.org/10.1016/j.desal.2010.08.028.

[112] Guo W, Ngo HH, Li J. A mini-review on membrane fouling. Bioresour Technol 2012;122:27-34. https://doi.org/10.1016/i.biortech.2012.04.089.

[113] Jiang S, Li Y, Ladewig BP. A review of reverse osmosis membrane fouling and control strategies. Sci Total Environ 2017;595:567-83. https://doi.org/10.1016/ j.scitotenv.2017.03.235.

[114] Aslam M, Charfi A, Lesage G, Heran M, Kim J. Membrane bioreactors for wastewater treatment: a review of mechanical cleaning by scouring agents to control membrane fouling. Chem Eng J 2017;307:897-913. https://doi.org/ 10.1016/j.cej.2016.08.144.

[115] Bagheri M, Mirbagheri SA. Critical review of fouling mitigation strategies in membrane bioreactors treating water and wastewater. Bioresour Technol 2018; 258:318-34.

https://doi.org/10.1016/i.biortech.2018.03.026.

[116] Sepehri A, Sarrafzadeh MH. Effect of nitrifiers community on fouling mitigation and nitrification efficiency in a membrane bioreactor. Chem Eng Process - Process Intensification 2018;128:10-8. https://doi.org/10.1016/i.cep.2018.04.006. 
[117] de Oliveira TS, Corsino SF, Di Trapani D, Torregrossa M, Viviani G. Biological minimization of excess sludge in a membrane bioreactor: effect of plant configuration on sludge production, nutrient removal efficiency and membrane fouling tendency. Bioresour Technol 2018;259:146-55.

https://doi.org/10.1016/ j.biortech.2018.03.035.

[118] Ahmad Z, Ujang Z, Abdul Latiff AA, Ahmat Nor NI. Effect on membrane fouling and cake resistance in a hybrid membrane bioreactor for palm oil mill effluent treatment. Int. Conf. Environ 2008:1-12.

[119] Chan YJ, Tan WJR, How BS, Lee JJ, Lau VY. Fuzzy optimisation approach on the treatment of palm oil mill effluent (POME) via up-flow anaerobic sludge blankethollow centered packed bed (UASB-HCPB) reactor. J Water Process Eng 2015;5: 112-7.

https://doi.org/10.1016/j.jwpe.2015.01.005.

[120] Poh PE, Chong MF. Upflow anaerobic sludge blanket-hollow centered packed bed (UASB-HCPB) reactor for thermophilic palm oil mill effluent (POME) treatment. Biomass Bioenergy 2014;67:23142. https://doi.org/10.1016/j. biombioe.2014.05.007.

[121] Dvorak L, Gomez M, Dolina J, Cernín A. Anaerobic membrane bioreactors-a mini review with emphasis on industrial wastewater treatment: applications, limitations and perspectives. Desalin Water Treat 2016;57:19062-76. https://doi. org/10.1080/19443994.2015.1100879.

[122] Uddin W, Khan B, Shaukat N, Majid M, Mujtaba G, Mehmood A, et al. Biogas potential for electric power generation in Pakistan: a survey. Renew Sustain Energy Rev 2016;54:25-33. https://doi.org/10.1016/j.rser.2015.09.083.

[123] Choong YY, Chou KW, Norli I. Strategies for improving biogas production of palm oil mill effluent (POME) anaerobic digestion: a critical review. Renew Sustain Energy Rev 2018;82:29933006. https://doi.org/10.1016/i.rser.2017.10.036.

[124] Khemkhao M, Techkarnjanaruk S, Phalakornkule C. Simultaneous treatment of raw palm oil mill effluent and biodegradation of palm fiber in a high-rate CSTR. Bioresour Technol 2015;177:1727. https://doi.org/10.1016/j. biortech.2014.11.052.

[125] Mao C, Feng Y, Wang X, Ren G. Review on research achievements of biogas from anaerobic digestion. Renew Sustain Energy Rev 2015;45:540-55. https://doi.org/ 10.1016/j.rser.2015.02.032. [126] Borja R, Banks CJ. Treatment of palm oil mill effluent by upflow anaerobic filtration. J Chem Technol Biotechnol 1994;61:103-9. https://doi.org/10.1002/ jctb.280610204.

[127] Gobi K, Vadivelu VM. By-products of palm oil mill effluent treatment plant - a step towards sustainability. Renew Sustain Energy Rev 2013;28:788-803. https://doi.

org/10.1016/j.rser.2013.08.049.

[128] Khemkhao M, Nuntakumjorn B, Techkarnjanaruk S, Phalakornkule C. UASB performance and microbial adaptation during a transition from mesophilic to thermophilic treatment of palm oil mill effluent. J Environ Manag 2012;103: 74e82. https://doi.org/10.1016/i.jenvman.2012.03.004.

[129] Zinatizadeh AAL, Mirghorayshi M. Effect of temperature on the performance of an up-flow anaerobic sludge fixed film (UASFF) bioreactor treating palm oil mill effluent (POME). Waste Biomass Valorization 2017;1-7.

[130] Choi W-HH, Shin C-HH, Son S-MM, Ghorpade PA, Kim J-JJ, Park J-YY. Anaerobic treatment of palm oil mill effluent using combined high-rate anaerobic reactors. Bioresour Technol 2013;141:13844. https://doi.org/10.1016/j. biortech.2013.02.055. 
